\title{
Organizational Structure and Collective Action: Lineage Networks, Semi- autonomous Civic Associations, and Collective Resistance in Rural China
}

\author{
Yao Lu and Ran Tao
}

\section{Full citation:}

Lu, Yao, and Ran Tao. 2017. "Organizational Structure and Collective Action: Lineage Networks, Semi-autonomous Civic Associations, and Collective Resistance in Rural China." American Journal of Sociology 122(6): 1726-74.

Corresponding Author:

Yao Lu

Department of Sociology

Columbia University

501 Knox Hall

New York, NY 10027

Email:yao.lu@columbia.edu

Telephone: 212-854-5442

Fax: 212-854-2963

Ran Tao

Department of Economics

Renmin University

Beijing, China

Email: rantao1972@gmail.com

\section{Acknowledgement:}

We acknowledge funding support from the Weatherhead East Asian Institute at Columbia University and the National Natural Science Foundation of China (Guojia Ziran Kexue Jijin) (71533007). We are grateful to Peter Bearman, Thomas DiPrete, Yong Cai, Gil Eyal, Shamus Khan, Ching Kwan Lee, Doug McAdam, Debra Minkoff, Steve Pfaff, Sidney Tarrow, Yang Su, Yanfei Sun, Feng Wang, Guobin Yang, and the AJS reviewers for pro- viding valuable suggestions at various stages of this research. We thank Ming Li and Jing Liu for excellent research assistance. 


\title{
Organizational Structure and Collective Action: Lineage Networks, Semi-autonomous Civic Associations, and Collective Resistance in Rural China
}

\begin{abstract}
Existing research on the relationship between organizations and social movements typically focuses on organizations' internal structure and explains the emergence and outcome of movements in separate frameworks. The literature also highlights a lack of organizational basis for collective action in non-democratic regimes. To bridge these gaps, the present study examines the distinct roles played by different organizations (embedded in distinct external structures reflecting state-society relations) in different stages of collective action (occurrence and success) in rural China. Using both quantitative and qualitative data, we study two types of organizations - first, informal lineage groups and second, semi-autonomous civic associations, exemplified by seniors associations. The results demonstrate that lineage groups serve as important mobilizing structures for collective resistance, but face limited success given their informal status and weak vertical linkages with the state. By contrast, seniors associations, which maintain close relations with authorities while conserving a high degree of autonomy, act as a genuine intermediary between government and aggrieved citizens, thus largely suppressing the occurrence of collective resistance. When collective action emerges, however, the associations can build on their legitimacy and vertical linkages to facilitate effective action. The findings provide a more nuanced understanding of the dynamics of contention in a non-democratic setting and the disparate roles different social organizations play in the process.
\end{abstract}




\section{INTRODUCTION}

Despite an early tradition in the social movement literature that views organizations as suppressing contention (Michels 1962 [1915]; Piven and Cloward 1992), accumulating evidence has endorsed resource mobilization and political process theories, which recognize social organizations as important mobilizing structures facilitating social movement (McCarthy and Zald 1977; Snow, Zurcher, and Ekland-Olson 1980; McAdam 1982; Morris 1984; McAdam, Tarrow, and Tilly 2001). This more recent strand of research has stressed the internal structure (or horizontal linkages) within organizations, defined as interpersonal or associational ties that provide a connective structure to foster solidarity and amass resources needed for collective action (Tilly 1978; Zald and McCarthy 1977; McCarthy 1996; McAdam et al., 2001; Tilly and Tarrow 2007; Tarrow 2011). It relies on "protest event analysis," which selects movements that have emerged and traces them back to study the organizational settings that birthed movements (Koopmans and Rucht 2002). This research strategy tends to exaggerate structural regularitiesthat is, how a diverse range of organizations plays similar roles in facilitating the emergence of social movements - and neglects the organizational conditions that constrain action.

A separate social movement literature investigates conditions for successful collective action. This line of research has emphasized organizations' interaction with their political environment to explain favorable movement outcomes (Gamson 1990; Amenta, Carruthers, and Zylan 1992; Giugni 1998; Cress and Snow 2000; Andrews 2001; Amenta, Caren, and Olasky

2005). We know, however, less about the role of social organizations during cycles of collective action, from their very emergence to their success or lack thereof. Political opportunity structures are dynamic, shaped and reshaped through strategic interactions between organizations that build 
the movement and power holders with which they are working. In this respect, organizations confront changing political environments in different stages of collective action (Powell and Friedkin 1987; Clemens 1996; McCarthy 1996).

Our objectives are two-fold. First, the present study transcends the question of whether organizations primarily facilitate or suppress collective action and examines how different types of organizations can play varied, even opposing, roles in the emergence of collective action. We supplement the conventional protest event analysis to incorporate situations where a movement erupts and where it fails to emerge. Second, we link movement emergence and success in a unified framework and study how different types of organizations perform varied roles in different stages of collective action. We move away from a static structural understanding to a more dynamic conceptualization of mechanisms undergirding the evolving role of organizations in contentious politics. In addressing the two goals, we theorize what types of organizations are likely to encourage mobilization or counter-mobilization and to be conducive or counterproductive to movement success.

We focus on a less systematically investigated dimension of organization, its external structure, defined as the vertical structural linkages that exist between organizations and external power structures (Oberschall 1973; Kriesi 1996). Such linkages can be embedded in both organizational and individual relations to the state and its actors that are formalized through institutional channels (Michelson 2007a). They guide interactions between challengers and power holders to create a distinct set of political opportunities and constraints (Oberschall 1973; McAdam 1982; McAdam et al. 2001). As such, we contend that organizations embedded in 
different vertical structural linkages (but similar horizontal linkages) can play distinct roles in the emergence and outcome of movements. Rather than treating vertical linkages as a dichotomy, either segmented from or integrated into the power structure (Oberschall 1973), we uncover an intermediate category of semi-integrated organizations, which are positioned to mobilize both state and societal resources to wield influence.

An organization's external structure is particularly relevant in non-democratic societies, where political opportunities are tightly circumscribed by the state (Wellman and Sik 1999; Osa 2003). In such contexts, vertical linkages shape access to political resources and opportunities for collective action. But collective action in these settings is largely perceived to lack an organizational basis because effective organizations are thought to be nonexistent or deficient (Cai 2010).

To advance our understanding of the organizational conditions underpinning collective action in non-democracies, we study rural China, which, in recent years, has witnessed unprecedented collective resistance $^{1}$ in response to official malfeasance (O'Brien and Li 2006; Bernstein and Lü 2008; Cai 2010). We find that social organizations play a greater and more intricate role in contentious politics in China than previously realized. A variegated spectrum of social organizations coexists, representing different models of state-society relations (vertical linkages) (Weller 2005; Spires 2011). They range from state corporatist entities to autonomous

\footnotetext{
${ }^{1}$ We use the term "collective resistance" to refer to the form of collective action most common in rural China in which people act together to defy abusive officials. It should be pointed out that such collective resistance is not analogous to social movements, which entail aggregates of collective actions that are more sustained, larger in scale, and have broader policy or social goals. In rural China, collective resistance is locally oriented, centers on modest and narrow claims (typically economic claims), and is rarely sustained.
} 
civil society groups, with semi-integrated semi-autonomous organizations in between. We compare two types of organizations that display marked differences in external structure but are embedded in strong horizontal linkages: traditional informal lineage groups (Tsai 2007) and semi-autonomous civic associations as exemplified by seniors associations (Pesqué-Cela et al. 2009). We examine both the occurrence and success ${ }^{2}$ (conditional on occurrence) of collective action using quantitative data from a longitudinal survey of rural China, supplemented with qualitative in-depth interviews.

We find that while these organizations are not primarily created to achieve social movement goals, they serve as agents for mobilization or counter-mobilization and play divergent roles in the subsequent development of collective action. Autonomous organizations are better poised to eschew external pressure and act on emergent political opportunities than more integrated organizations. Once collective action is underway, however, more integrated organizations gain power as they leverage their vertical linkages to gain access to the political system, whereas a high degree of autonomy turns out to be counterproductive. Notably, semiautonomous organizations emerge as a prominent force in state-society conflict because they can adapt to changing political circumstances either through intermediation or contention.

\section{BACKGROUND}

\footnotetext{
${ }^{2}$ This paper does not engage in the debate about what constitutes successful collective action. Rather, we measure "direct" success, that is, the intended results of collective petitions-whether petitioners' claims were resolved - for which we have information. This definition, while narrower, offers specifiable outcomes for analysis. It is a suitable simplification in the China setting, where petitions focus on specific local economic or social grievances rather than making broader democratic claims. Throughout the paper, we use the terms "success" and "effectiveness" interchangeably.
} 


\section{Organizational Structure and Emergence of Collective Action}

Accumulating evidence grounded in resource mobilization and political process traditions posits that movements develop within "mobilizing structures," established social and organizational bases, that foster group solidarity and marshal material and human assets into collective action (McCarthy and Zald 1977; Snow et al. 1980; McAdam 1982; Morris 1984; McAdam et al. 2001). They take diverse forms, ranging from informal groups based on interpersonal networks (Evans 1979; Diani and McAdam 2003) to a wide array of civic associations and formal social movement organizations (McCarthy and Zald 1977; Snow et al. 1980; McAdam 1982; Morris 1984; McAdam et al. 2001; Staggenborg 2002; Sampson et al. 2005; Della Porta, Kriesi, and Rucht 2009). What these organizational forms have in common is their internal structure (or horizontal linkages), whether based on interpersonal or associational ties, that can galvanize members into collective action (Tilly 1978; McCarthy 1996; Diani and McAdam 2003). Whereas insurgents sometimes create an organizational vehicle for action, more often they mobilize through the process of "social appropriation"__"appropriate an existing [non-political] organization and the routine collective identity on which it rests" (McAdam 2003, p. 292).

Despite the prevalent view that existing social relations exert a largely positive influence on a group's mobilization capacity, an early tradition in social movement research recognizes that organizations come in different forms and some can suppress collective action (Michels 1962 [1915]; Piven and Cloward 1992). This tradition, however, has not gained much traction in the recent literature due to a lack of systematic supporting evidence and methodological and conceptual issues. Methodologically, the prevailing research design adopts "protest event analysis" and selects on collective action that has emerged (Koopmans and Rucht 2002). It 
restricts attention to a class of organizations with strong horizontal linkages that facilitate social movements and masks the numerous circumstances under which organizations impede movements (McAdam 2002). A more appropriate design would consider situations where movements break out and where they fail to erupt. Conceptually, the literature has not concretely theorized and tested what types of organizations are likely to facilitate or inhibit collective action, especially with respect to an organization's external structure ${ }^{3}$ - the vertical structural linkages that exist between organizations and external power structures (i.e., the state and its actors) (Oberschall 1973; Kriesi 1996).

Vertical linkages shape movement emergence. Political process theory holds that organizations operate within the limits of existing broader political opportunity structures, which affect the space for contention (McAdam 1982; McAdam et al. 2001). This external environment is inherently shaped by vertical linkages between the organization (challenger) and the power structure (target). Previous research delineates erratic interactions between activists and authorities, but these interactions have not been formally understood as an aspect of organizational structure. We contend that these vertical linkages encompass the concept of political embeddedness (Michelson 2007a). They represent structural relations of organizations to the state and its actors, embedded in bureaucratic, instrumental, or affective organizational and individual ties, which become formalized through institutional channels that engage the organizations.

\footnotetext{
${ }^{3}$ We conceptualize external structure as the vertical linkages with state actors. We acknowledge that organizations can have external linkages with societal actors such as social media and other civic organizations. But in our study setting and period external structure is largely composed of the linkages between organizations and the state and its actors, because rural China suffers from a slow telecommunication development and the Chinese state forbids inter-organizational linkages.
} 
Organizations embedded in different vertical linkages can play varied roles in movement emergence. Those segmented from the power center enjoy considerable free spaces and are better able to deflect state control and counter-mobilization pressures. They are thus poised to act on emergent political opportunities and to gravitate toward collective action (outsider strategies). By contrast, organizations vertically integrated into the power structure are subject to greater state control and vulnerable to state counter-strategies that aim to contain outright mobilization. These organizations, to survive and sustain organizational benefits, run the risk of cooptation, gradually abandoning their original goals. The conservative orientation of integrated organizations can thus impose obstacles to mobilization, especially disruptive ones, thereby inhibiting collective action. Instead, these organizations are likely to engage in moderate claimsmaking and seek resolution from within the system (institutionalized insider strategies).

\section{Organizational Structure and Success of Collective Action}

Once movements emerge, they follow different trajectories: a few achieve success; others gradually dissipate or are curtailed by repression. A critical question is what factors contribute to the success of collective action. Early research has stressed internal characteristics of movement organizations (Gamson 1990; Giugni 1998). Strong horizontal linkages and a centralized structure create a more enduring organizational environment to sustain social movements (Gamson and Schmeidler 1984; Gamson 1990). Subsequent research points to the role of external political context and its interaction with organizations' internal characteristics in conditioning success (Amenta et al. 1992, 2005; Cress and Snow 2000). The broader context shapes political opportunities available to insurgent organizations and affects the responses of 
political elites that determine movement outcomes, which differ in strength (responsive or unresponsive) as well as substance (supportive or repressive) (Giugni and Yamasaki 2009). Favorable contexts can arise from the presence of sympathetic bureaucrats and influential allies within the institutions targeted for change (Amenta et al. 1992; Tarrow 2011). These political actors bridge an organization and its constituencies to political institutions and their decisionmaking processes.

Which types of organizations are capable of accruing advantages from bridging relations with political institutions? These relations are often perceived as pre-existing informal, noninstitutionalized ties, or as a result of ad hoc interactions between challengers and political actors. We propose that these ties can be inherently embedded in the external structure of organizations, which determines the nature and strength of the relations between organizations and authorities. As such, how organizations are structured externally affects their capacity for staging successful movements and exerting a political influence.

After a movement begins, organizations integrated into the power structure can benefit from their vertical linkages, which allow them access to key political processes and their powerful players. This institutional access secures a favorable political environment. In this respect, a high degree of separation from the political system limits the efficacy of insurgent organizations as it deprives them of crucial resources existing beyond their constituencies.

\section{Linking Emergence and Success of Collective Action}


The processes underlying the emergence of collective action and its success have largely been investigated separately. Viewing the phenomena distinctly obscures an intriguing question-how do organizational roles evolve over the course of a movement? Is the type of organization that is highly instrumental in mobilization also conducive to successful outcomes? Admittedly, there is considerable continuity in the processes of movement emergence and its development. Organizational attributes crucial for mobilization, such as its horizontal linkages, also facilitate movement development (Gamson 1990).

Nevertheless, political opportunity structures shift over the course of collective action through interactions between insurgents and state actors. As such, organizations tend to confront changing opportunities (Powell and Friedkin 1987; Clemens 1996; McCarthy 1996), which amplify or dampen the impetus for mobilization and open or limit the political space for successful action. Linking emergence and success of collective action in a unified framework provides an understanding of the evolving role of organizations and the specific mechanisms that serve to empower or constrain organizations.

Different organizations can play distinct roles at different stages of collective action. The prospect of seizing emerging political opportunities and securing a favorable environment for success depends on the vertical linkages of organizations. In the initial stage, effective mobilization stems from a combination of strong horizontal linkages and a capacity to circumvent state suppression. Autonomy from the power structure can facilitate movement emergence, whereas too much integration may compromise an organization's autonomy and ability to stage contentious action against the state (Cloward and Piven 1984; Gamson and 
Schmeidler 1984). But once collective action is underway, organizations capable of leveraging their vertical linkages tend to be more powerful in influencing the outcome of their action.

How do we comprehend the potential that the same structural conditions that foster mobilization are also likely to undermine a movement's effectiveness, and vice versa? To uncover these patterns, it is necessary to study the success of collective action conditional on its occurrence, which avoids confounding the role of organizations in the initial mobilization and in movement success. Conceptually, such research is congruent with the idea of organizational adaptability (Powell and Friedkin 1987; Clemens 1996; McCarthy 1996; Minkoff 1999), or organizational amphibiousness (Ding 1994), the extent to which an organization responds to a shifting political environment by adjusting its strategies and processes. The direction of change can vary. Some organizations tend to become more conservative over time to secure organizational survival, whereas others experience proactive change and turn more militant even in the face of external pressures (Minkoff and Powell 2006). The most effective organizations are capable of exerting multiple mechanisms of influence by oscillating between routine negotiations with political actors and mass-based tactics (Staggenborg 1989; Ganz 2000; Andrews 2001). This adaptive reconfiguration between contained (insider) and confrontational (outsider) strategies allows organizations to navigate or even transgress the boundaries of the polity. But what type of organization encompasses this adaptability?

The answer may lie in the degree of integration, which requires moving beyond the dichotomy of "segmentation" and "integration" to incorporate varying levels of vertical linkages. A semi-integrated structure with a high degree of autonomy is likely to be more effective than 
either complete segmentation or entrenched structural integration. Organizations with these hybrid constellations can assume dual roles of cooperation and contention. In so doing, they exploit their insider connections and familiarity with the system while resisting state cooptation, acting as true boundary-spanning organizations (Fox and Cooper 2013).

\section{Organizational Basis of Collective Action in Non-Democratic Societies}

The knowledge of the relationship between organizations and social movements is predominately derived from Western democracies, where rights of association and movement are regime-backed (Tilly and Tarrow 2007). There is growing research in contentious politics in non-democracies. But collective action in these settings is largely thought to lack an organizational basis because social organizations, if they do exist, tend to be tightly circumscribed by the state and thus unproductive of resistance (Cai 2010; Osa 2003; Osa and Corduneanu-Huci 2003; Schock 2005). Instead, popular mobilization relies on informal interpersonal networks, which are formed within established social spaces and independent of state control, as the primary social structure (Zhou 1993; Zhao 1998; Wellman and Sik 1999; Osa 2003; Lee 2007; Wright 2008; Chan and Ngai 2009; Cai 2010; O’Donnell and Schmitter 2013). The "micro-mobilization community" composed of these ties, however, tends to be temporary and demobilizes when its demands are addressed or under the pressure of the state (Cai 2010).

The absence of an organizational perspective masks the development and complexity of social organizations in non-democracies. A closer investigation reveals the co-existence of a spectrum of social organizations, comprised of both grassroots and government-organized 
organizations (Gallagher 2004; Weller 2005). Recent research has examined the operation of civic organizations and their strategic relationship with the state (Spires 2011; Teets 2013). The role of social organizations in collective action has not been systematically examined: Do civic organizations serve as a genuine source of countervailing power and hold strong potential for concerted collective action (Warren 2001; Avritzer 2002)? Or are they mainly "state corporatists," created and controlled by the state to help fend off political challenges and consolidate authoritarian power (Riley 2005; Streeck and Kenworthy 2005; Unger 2008)?

The relationship between civic organizations and collective action tends to be especially varied in non-democratic settings. Unlike the free spaces created for contention in democracies, collective action is deemed a serious threat to authoritarian rule. State authorities are thus particularly concerned with containing collective action than in democracies. This sets the stage for the importance of intermediary organizations between the state and society, which the state seeks to identify or create in order to inhibit or preempt collective action (Petras and Veltmeyer 2006; Lee and Zhang 2013). When collective action takes place, state actors in non-democratic regimes hold substantial decision-making power in shaping contentious outcomes (Cai 2010). Because government mandates are not granted through electoral institutions, authorities lack the pressure to respond to popular contention, except for large-scale disruptions, and may even resort to repression to undermine collective resistance. As a result, connections to power holders become an important resource for navigating and influencing state-guided processes. Moreover, cycles of contention may vary. In democracies, protests are easy to come by and are typically followed by negotiations. In non-democracies, by contrast, initial negotiation is preferred with a 
goal of suppressing collective action. If negotiations fail, there can be a change in strategy (i.e., to mobilization) and in the relationship between claimants and the state.

These conditions suggest that an organization's vertical linkages are especially important in non-democratic regimes, which open or block political opportunities and generate external support or pressure. More autonomous organizations, where the state's reach is limited, are likely to serve as a vehicle for contention. More integrated organizations, on the other hand, are likely to be converted into instruments for containing state-society conflicts. Neither fully corporatist nor fully autonomous organizations, however, are capable of exerting substantial political influence because their resources are singular (Unger 2008). Semi-autonomous organizations, which are partly aligned with the state but also able to pursue independent agendas, have particular advantages. They tap into both state and societal resources for interest intermediation, or when needs arise, for counterbalancing the system.

\section{THE STUDY SETTING}

\section{Land Requisition as a Leading Source of Rural Unrest}

The present study was conducted in rural China, which in recent years has been swept by increasing collective resistance (O’Brien and Li 2006; Bernstein and Lü 2008; Cai 2010). The primary trigger of collective resistance is local government requisition of peasants' land $(\mathrm{Yu}$ 2007). After the central government abolished agricultural taxes in the early 2000s, land requisitions replaced tax burdens as the leading cause of collective resistance (Kennedy 2007). In land requisitions, local cadres dispossess farmers of their land, often by force, pay them far below market value, and pocket the lion's share of the profits for themselves. 
Abusive land practices are partly a result of administrative and fiscal decentralization that have accompanied China's economic reforms. Administrative decentralization has led to declining effectiveness in the central state's control over local society, ${ }^{4}$ creating opportunities for official malfeasance against powerless peasants (Guo 2001). Fiscal decentralization exacerbates this tendency by forcing local governments to generate most of their revenues. Coupled with booming land values, local officials have come to rely on land requisitions for revenue generation, typically leasing out land use rights for nonagricultural purposes (Wong 1997). Land requisition has gradually become the main business of local governments throughout the country, providing between $20 \%$ and $70 \%$ of local governments' administrative budgets (Lin and Ho 2005; Su, Zhao, and Tao 2013).

The problem of abusive land requisition fundamentally results from a lack of transparency in land property rights, as the owner of agricultural land in China is the "collective." This legal ambiguity has given local state wide latitude to claim itself as the de jure owner of rural land, while peasants are deprived of non-agricultural developmental rights on their own land (Lin and Ho 2005). Under such a system, land requisition has to be initiated by local governments, which not only decide where and how much land is to be appropriated but also the level of compensation (Su et al. 2013). County governments often set land development plans and propose terms for land requisition. The township governments then carry out

\footnotetext{
${ }^{4}$ In China, the formal administrative hierarchy below the central government consists of the following levels in descending order: province, prefecture (municipal), county, and township. Township is the lowest formal administrative level of state authority. Villages are within townships, but are not part of the formal administrative structure. Villages are self-governing units, with government-like institutions such as the village committee and party branch. Village cadres are elected by peasants, in theory, but township governments often have a strong influence on election results.
} 
negotiations with village cadres (who represent the "collectives"), and together they coerce farmers to accept government-set terms, which come with little or no compensation. Local governments then lease the land to commercial land developers at (much higher) market price. The profit is misappropriated by different levels of cadres. In this process, village cadres often develop entrenched interests in colluding with upper-level authorities to depress peasants' compensation to maximize profits (Su et al. 2013). Such abusive land requisitions naturally fuel farmers' resistance.

\section{Rural Collective Resistance}

The most common mode of peasant collective resistance is collective petitioning, with more than five people lodging a formal complaint against local authorities (usually village or township officials) with authorities above the village level (Chen 2008). ${ }^{5}$ In 1995, complaint agencies at the county level and above received 4.97 million petitions; this number rose to 13.73 million in 2004 (Cai 2010). Citizens can present petitions by sending letters to pertinent authorities or by visiting complaint departments in higher-level government agencies. Petitioners generally begin by lodging complaints at the township level. When they fail to receive meaningful responses, they may petition upper-level authorities.

Petitioning represents an institutionalized form of collective resistance because petitioners seek help from the government and government officials have the discretion to judge whether their intervention is necessary (Cai 2010). Hence, the petition system represents the rule

\footnotetext{
${ }^{5}$ According to the Regulations on Letters and Visits (State Council 2005), citizens filing petitions must elect no more than five delegates to represent themselves. A petition with more than five participants thus reflects an act of defiance against authoritarian rule, and is regarded as collective resistance (Yu 2007).
} 
of man, not the rule of law (Minzner 2006). For this reason, petitions are often futile (Cai 2010). At the most extreme level, petitioners face crackdowns, as many have been intercepted, arrested, or detained.

More direct, non-institutionalized forms of collective resistance have also been increasingly adopted. These include demonstrations, sit-ins, traffic blockades, office blockades, construction obstruction, and clashes with officials or the police (O'Brien and Li 2006). These modes of action display open defiance and tactical escalation. From 1993 to 2005, the number of such incidents increased tenfold from 8,700 to 87,000 (Yu 2007). Some peasants bypass petitions and take their grievances directly to the street. Others file petitions but augment their chances with direct action. These escalated actions make the grievances known; they also place pressure on local governments by paralyzing social order and posing threats of intervention from above (Cai 2010). They tend to have a moderately better chance of obtaining a response than petitions.

Scholarship on collective resistance in rural China has focused on leaders and activists, who are more likely to be men, better-educated (e.g., former teachers), former cadres, bold and well informed (e.g., demobilized soldiers), or with family connections to local authorities (Michelson 2007b; Bernstein and Lü 2008; Li and O'Brien 2008). During mobilization, activists usually rely on interpersonal networks or ties formed around shared experiences to recruit participants (Vala and O’Brien 2008).

Recent work also examines the conditions for successful collective resistance (Cai 2010). The chance of redress increases when resisters are able to generate substantial political pressure 
on local authorities, for example, by staging disruptive actions. Another important mechanism for success is connections with influential state agents who have authority over lower-level officials, sometimes exploiting divides within government agencies at local levels (O'Brien and Li 2006; Cai 2010). These networks generate critical information and support from within the state, moving a complaint onto the agenda of state authorities, and possibly influencing the decision-making of state agencies.

The existing literature provides invaluable insights but is based on case studies or smallscale quantitative data; it also pays limited attention to the role of social organizations. To bridge the gap, the present study combines large-scale quantitative analysis and interview data to assess the organizational basis of rural collective resistance.

\section{The Organizational Sphere}

Since the 1980s, China has undergone a civil society revolution. The state has encouraged the development of civic associations to promote interaction between government and societal forces and to take over the state's responsibility in service provision (Howell 2007). Over the past several decades, civic associations have grown substantially, giving rise to a diverse organizational sphere reflecting complex forms of state-society relations (Saich 2000; Zhang and Baum 2004; Weller 2005; Pesqué-Cela et al. 2009).

At one (statist) end, there are state-created and -controlled organizations, which comprise a majority of Chinese civic associations (Saich 2000; Yu 2007; Unger 2008). They include industrial and business associations, academic and professional associations, and associations 
dedicated to other fields of activity or specific social groups such as the Women's Association, Communist Youth League, and Family Planning Association. Many of these associations are channeled into social services delivery. Unlike typical civic organizations prevalent in Western countries, they are required to register under a supervisory state agency and their leaders are appointed by the government; they also rely heavily on the state for finances and are subject to close supervision (Saich 2000; Unger 2008). As such, these state corporatist associations are essentially auxiliary organs of the state, operating with little autonomy (Weller 2005). In reality, they often exist in a state of paralysis, described by many as "existing only in name" (mingcun shiwang) (Tao et al. 2013). These associations are unlikely to become involved in collective resistance, and are thus not the focus of this study.

At the other (societal) end are civic associations with genuine autonomy, neither created nor controlled by the state (Zhang and Baum 2004). These grassroots organizations include unregistered non-government associations and traditional forms of social organizations that revolve around kinship and religious activities. For them, the creation, selection of leaders, finances, and activities are mostly self-directed, although some are loosely and intermittently linked to the state (Saich 2000). Despite their unauthorized status, these autonomous associations are allowed to exist as long as they remain small, local, and apolitical, addressing mainly social services and cultural activities (Weller 2005).

In between statist and societal organizations, semi-autonomous civic associations have gained prominence (Tao et al. 2013). They are created or officially sanctioned by the state but retain a high degree of autonomy, as their leaders do not hold concurrent positions in the 
government and they manage their own decision-making. They include non-government organizations that are registered with the state but maintain operational autonomy (Teets 2013). In rural areas, they are exemplified by seniors associations (discussed in detail below). These organizations, despite an official status and a close relationship with local governments, are by no means controlled by the state. This enables them to structure a complex relationship with the state in ways that safeguard community interests while evading state intrusion (Deng and Ruan 2006; Hurst et al. 2013).

Scholars have examined the operational strategy of autonomous and semi-autonomous organizations in urban China. This line of research shows that organizations oriented toward service delivery can function fairly efficaciously, sometimes engaging in formal or informal collaboration with the local state (Spires 2011; Teets 2013). The relationship between these organizations and an authoritarian state can be understood within a framework of "contingent symbiosis," in which interactions between the two entities take place in a way that addresses social needs while mitigating local grievances (Spires 2011).

The present study takes a step further and examines the implications of different social organizations for contentious politics. In doing so, we link the often separate literature on collective resistance and the organizational sphere in China. We focus on two types of organizations - civic associations with genuine autonomy (lineage groups) and semi-autonomous civic associations (seniors associations). Both are characterized by strong horizontal linkages (based on social or associational ties) but display marked differences in vertical linkages. 


\section{LINEAGE NETWORKS AND COLLECTIVE RESISTANCE}

We first examine a type of autonomous organization formed on patrilineal lineage ties. ${ }^{6}$ Lineages have long been a salient feature in cultural and social life in rural China (Cohen 2005; Liu and Murphy 2006). It is common to find villages with strong lineage networks - that is, a large proportion of residents descend from the same (or a few of the same) patrilineal ancestors and share the same surname. Lineages draw on their networks for collective activities, from traditional rituals of ancestor worship to farming and other social and recreational events. These activities reinforce group identity and a sense of obligation.

Relations between lineages and the state have passed through several phases.

Historically, lineages served as a vehicle for the integration of state and local society. They have even taken on governmental functions such as property protection and tax collection (Huang 2008). During the Mao era, state bureaucracy expanded down to the village level. Wary that lineage might counterbalance state power, the government forced peasants to break away from the lineage system and integrate into collective farms and state grassroots administrative hierarchies (He 2003). The state also banned traditional lineage activities and destroyed lineage establishments such as lineage halls.

\footnotetext{
${ }^{6}$ Studying lineage network structure has several advantages over studying the presence of lineage associations in understanding the organizational environment embedded in lineage networks (Murphy et al. 2011). First, it allows us to better measure the strength of lineage networks. Also, lineage associations often come in different forms; some lineages may not have long-standing associations but set up temporary organizations for specific events (He 2003). These situations are not captured in the data. Further, as discussed below, a measure of lineage network structure allows us to distinguish different types of lineage configuration (monopolistic vs. oligopolistic), which have different implications for collective resistance.
} 
With the dismantling of rural collectives since the beginning of economic reforms, the lineage system has undergone a remarkable revival in rural China (Xiao 2001; He 2003). Ancestral halls have been rebuilt and lineage traditions reactivated. Lineages have gradually regained their influence in village affairs. Strong lineages influence village elections to ensure members entry into village power operations (Thurston 1998). They also function as informal solidarity institutions, which interact with formal institutions to enhance village governance (Tsai 2007).

Local governments have become increasingly wary of lineage resurgence as a potential threat to the regime's ruling power (Xiao 2001; He 2003). In some villages, strong lineage networks are mobilized to unite villagers to resist implementation of unpopular birth control policies (Peng 2010). To strengthen the party's rule in the countryside, local governments often monitor lineage activities closely and periodically put limits on lineage power, for example, by requiring official approval for organizing large-scale lineage rituals and occasionally by bringing leaders of large lineages under their control.

Against this backdrop, a critical yet underexplored question is how lineage networks shape collective resistance directed at the state. ${ }^{7}$ To the extent that lineage networks forge group solidarity and a sense of moral obligation, they facilitate mass mobilization when lineage interests are threatened. These ties also can invoke informal social control to encourage participation and help overcome problems of free riding and defection. Even when lineages are

\footnotetext{
${ }^{7}$ Our focus differs from previous research. Tsai (2007) examines the role of lineage networks in intravillage governance. Peng (2010) studies how lineage networks help evade state policy implementation within the village. Neither study deals directly with collective action directed at state authorities above the village level.
} 
inert in routine settings, these established identity-based ties can be reactivated to serve as mobilizing structures in times of crisis. In the meantime, this indigenous organizational structure provides free spaces largely independent of state control. The free spaces effectively deflect state counter-mobilizing pressures. Therefore, we hypothesize that in the presence of local grievances, villages with strong lineage networks are more likely to engage in collective resistance than those with weak lineage networks (Hypothesis 1a).

Given their vertical segmentation and unauthorized status, however, lineages have tenuous, sometimes even conflictual, relations with state authorities above the village level, who largely shape the outcomes of collective resistance. Hence, whereas lineages often play a crucial role in intra-village affairs, they lack the organizational legitimacy and vertical linkages necessary to secure favorable political conditions for successful collective resistance. ${ }^{8}$ Local state authorities remain suspicious of lineage organizations as a potential breeding ground for rebellion and do not make concessions easily to these informal groups. Doing so is likely to trigger unconstrained contention. Therefore, once underway, collective resistance in villages with strong lineage networks is not necessarily more effective than that in villages with weak lineage networks (Hypothesis 1b).

The structural characteristics and roles of lineages and seniors associations are summarized in Table 1.

\footnotetext{
${ }^{8}$ Whereas some lineages may have members holding position in higher-level governments, this is not universal (He 2003). When these ties do exist, they tend to be limited and informal compared to the more formalized and pervasive vertical ties forged by seniors associations.
} 


\section{SEMI-AUTONOMOUS CIVIC ORGANIZATIONS AND COLLECTIVE RESISTANCE:}

\section{THE CASE OF SENIORS ASSOCIATIONS}

The second type of organization we study is the semi-autonomous civic association, which in rural China is exemplified by seniors associations (old people's associations, or laoren xiehui). Seniors associations are found across rural China in developed and underdeveloped regions (He 2003). They were first set up by the state in the late 1980s to relieve its welfare obligations for older rural residents, who were ineligible for pensions. By 2005, there were over 317,000 seniors associations nationwide (Deng and Ruan 2006). These associations serve the needs of the elderly, especially those who are ill or poor. They also carry out cultural and social activities such as ceremonies and local burial rituals (He 2003; Hansen 2008).

As semi-autonomous organizations, seniors associations combine their official status and modern structure with substantial autonomy. In their operations, the associations often make their own decisions and raise and manage funds largely independent of government interference (Chen 2012; Hurst et al. 2013). Such operational autonomy is mostly derived from the traditional authority accorded to the elderly ${ }^{9}$ as well as the personal prestige of well-regarded association members, many of whom are retired teachers or retired cadres (Deng and Ruan 2006; Hansen

\footnotetext{
${ }^{9}$ Seniors associations are not equivalent to informal lineage groups, although the two can overlap to a degree (He 2003). Seniors associations are found across villages with different social structures (weak or strong lineage networks). Even in villages with strong lineage networks, membership and service of seniors associations reach a larger proportion of the village population than lineages. In some villages, lineage organizations may be integrated into seniors associations. But even so, the overlap exists in membership, not leadership. In our data across all sampled villages, the overlap in leadership occurred in only three of them. Leaders of seniors associations are mostly retired village or township cadres (65\%) or retired teachers $(20 \%)$. In contrast, lineage leadership is determined by seniority (nianling) and generational status (beifen) (Feng 2009). Lineage leaders are typically the most senior male in the family of the ancestor's eldest son, often having no government background. At the level of regular association membership, there is more overlap with lineages than at the leadership level. But in general, seniors associations represent a formalized form of elder authority largely independent of the lineage structure in the village.
} 
2008; Chen 2012). Personal prestige and organizational autonomy afford associations considerable popular support, which enables them to reach the entire village and build community-wide ties (horizontal linkages). These horizontal ties are based on members' associational ties combined with the family and social networks of the seniors in a village. Unlike lineages that incorporate only those in the same patrilineage, seniors associations are able to bridge different social groups to forge community-wide networks (Deng and Ruan 2006).

The official status of the associations formalizes senior authority into their organizational structure in a way that ensures their administrative legitimacy and grants them access to the political system. As such, the association holds close vertical connections with the local state, both through establishing formal institutionalized working relations with authorities and through formalizing pre-existing social connections with authorities based on members' official background. Coupled with its popular support, the association possesses the capacity to coordinate diverse interests and mediate state-society disputes (Hurst et al. 2013), an ability increasingly valuable alongside the waning authority of formal government and strained local state-society relations in rural China (Hansen 2008).

By virtue of their distinct external structure, seniors associations establish close and elaborate relations with the state and perform a range of state and society functions. Local governments consciously cultivate instrumental relationships with the associations to tap their authority and persuasive power for local governance, especially in implementing contested policies such as birth control policy and land requisition (Hansen 2008). In doing so, the associations enter into cooperative relations with the state. This allows them to serve as an 
intermediary between local state and society, conveying official messages to the peasants while bringing village needs to the attention of authorities (Hurst et al. 2013). Therefore, the presence of seniors associations as vehicles of interest intermediation can restrain local grievances from flaring up, thereby suppressing collective action; by contrast, villages where seniors associations are absent tend to lack effective mechanisms for handling local state-society disputes, which are likely to escalate into collective resistance (Hypothesis $2 a$ ).

Their hybrid structure affords seniors associations considerable adaptability. Rather than solely assuming the mediating role, the associations can reconfigure a cooperative relationship with the state into a competitive one in order to pursue community interests, if circumstances necessitate (i.e., when mediation fails). When turning to contentious tactics, the associations can exploit their organizational autonomy to deflect state control, while simultaneously capitalizing on their mass support and organizational skills for mobilization. Once collective resistance is underway, the associations benefit from their semi-official status, which provides a high degree of legitimacy and institutional access in pressing their claims. Their vertical linkages can be translated into political assets, which help the associations navigate the system, develop effective tactics, and secure official support for successful collective resistance (Hansen 2008; Chen 2012). Therefore, when collective resistance begins, seniors associations can facilitate it to achieve desired outcomes (Hypothesis 2b).

\section{DATA AND METHODS}

\section{Data}


Data for this study are from the Rural Survey of Land, Migration, and Local Governance in China. The survey was carried out by the Center for Chinese Agricultural Policy (CCAP) at the China Academy of Sciences. The survey consisted of two rounds. The first round was conducted in 2004-2005 using a multistage stratified sampling procedure. First, the country was divided into six commonly recognized geographical regions (State Council Development Research Centre 2002), and one province was randomly chosen from each region: Shaanxi (Northwest), Sichuan (Southwest), Hebei (North-Central), Jilin (Northeast), Jiangsu (East/Central Coast), and Fujian (Southeast). All counties in each province were then sorted into five strata (quintiles) according to per capita gross industrial output. One county was randomly selected from each stratum, yielding a total of 30 counties. Next, all townships in each selected county were sorted into two groups according to per capita net income — above and below the median. One township was randomly selected from each group (a total of 60 townships). Following the same procedure, two administrative villages were chosen from each township (a total of 120 villages). Serious flooding prevented data collection in 4 villages, resulting in a total of 116 villages. The second round was conducted in 2008 and sought to reinterview all sample villages. Three villages were not reinterviewed due to massive disruptions caused by the 2008 Sichuan earthquake. Therefore, 113 villages were interviewed in both periods and included in the analysis.

Village data were gathered in both waves. Village-level information on demographic and socioeconomic characteristics, and rural associations was obtained from village officials (party secretaries, village heads, and accountants) and leaders of rural associations. Such information was available from 2004 to 2008 . The information was verified with village official statistics to ensure accuracy. 
Household data were also gathered. Specifically, a random sample of 20 households based on village registration lists was chosen in each village. In each household, one adult was randomly selected for interview. The household-level data were used to derive information on village collective resistance from 2004 to 2008. Because of the sensitivity of the subject, responses from local officials tend to be unreliable. Likewise, the survey did not ask about respondent's own participation to avoid putting them at risk. Instead, each respondent was asked to report collective incidents that had occurred in the village, regardless of their own participation. Each did so by answering a series of structured questions about timing, reasons, form (collective petition, or one of the non-institutionalized forms of collective action), scale, and outcome of each incident. Trained project personnel, who were graduate students and faculty from local universities and who speak local dialects, synthesized responses from all respondents in each village to obtain a time series of collective incidents that occurred each year. This was done by matching on the information on timing, reasons, and form for each reported incident and coding them to one or different incidents of collective action. When there was ambiguous information or when respondents provided discordant information, the respondents were recontacted or revisited to verify details. The strategy of cross-validation across multiple informants improves accuracy and reduces underreporting. Once event identification was completed, we integrated the event data with the village-level data.

The survey was supplemented by in-depth interviews conducted in 61 villages across 40 townships from all 6 sampled provinces. The interviews were conducted mainly during the 2005 and 2008 surveys, with periodic revisits and follow-up interviews to selected villages between 
2009 and 2014. The interviews were led by two CCAP-affiliated researchers, who ran the survey (including one of the authors in this paper), with assistance of graduate students (who carried out the quantitative survey in the area) and local informants. The interviews were conducted with well-informed villagers, village/township cadres, and local association leaders, based on a list of semi-structured questions on local governance, local conflicts, and collective incidents. A total of 127 interviews were completed over the years, including those from 40 villagers, 52 village/township cadres, and 35 association leaders.

\section{Variables}

The first set of dependent variables indicates the occurrence of collective petitions. Specifically, we constructed three dichotomous variables reflecting different scales of collective petitions. The first variable measures whether any collective petition (with more than 5 complainants) occurred in a village in each year from 2004 to 2008 . The second and third dichotomous variables measure, respectively, the occurrence of collective petitions with more than 30 and more than 50 participants, ${ }^{10}$ which are categorized as medium and large-scale collective incidents according to the "Emergency Plan for Preventing and Dealing with Mass Incidents" administered by local governments ( $\mathrm{Yu}$ 2007). This distinction allows us to assess the role of social organizations in collective resistance of various scales.

The second set of dependent variables measures the occurrence of non-institutionalized collective resistance (including protests, demonstrations, sit-ins, blockages of roads or government buildings, obstruction of construction projects, and physical confrontations with

\footnotetext{
${ }^{10}$ In our data, the median size of collective petitions and protests is 15 and 40, respectively.
} 
police or officials; hereafter for parsimony we use "protests" to represent them). Again we constructed three dichotomous variables, with 1 indicating, respectively, the occurrence of any protest, protests with more than 30 participants, and those with more than 50 participants.

The third set of dependent variable measures success of collective petitions. This variable indicates whether the issue presented in each petition was fully or partially resolved (considered a success, which usually entails increased compensations or removal of corrupt officials). If the problem was not solved, or if petitioners were intercepted or repressed, it was deemed unsuccessful. Because the question was asked in a neutral and concrete way, a high degree of consensus among respondents was achieved.

The main predictors are the presence of a seniors association and lineage network structure. The former is defined by whether the village has a seniors association, for which the information is directly available. For lineage structure, we distinguish villages with a monopolistic structure (dominated by a single lineage), an oligopolistic structure (dominated by two or three large lineages), and mixed-surname villages (where multiple descent groups exist, and none has sufficient strength to dominate village life). Monopolistic and oligopolistic villages are both embedded in strong lineage networks; they are also characterized by different degrees of intra-lineage solidarity and inter-lineage conflict (Kennedy 2002; Murphy et al. 2011), which may have implications for collective resistance. The measure of lineage structure was constructed using cluster analysis with information on diversity of large surname clans (daxing) in the village - namely the percentage of households belonging to the largest surname clan and the percentage of households belonging to the three largest surname clans (more details in 
Appendix A). Note that in rural China, daxing is a common spoken term for lineage (Feng 2009). Hereafter, we use the term lineage (rather than daxing) for clarity. The procedure discussed above takes into account not only the absolute size of the largest lineage but also how it is positioned relative to other lineage groups.

We control for whether land requisition occurred in a village in a given year, which is the major source of local grievances and often triggers disputes over related issues such as local governance and elections (Yu 2007). We also control for village religious organizations, which carry out a multitude of religious activities and may provide a ground for collective resistance. The first measure is the presence of temples (Buddhism, Taoism, or other Chinese popular religions) in the village. The second variable is the presence of Christian churches or Islamic mosques (the latter are very few). The distinction between temples and churches is relevant for our study, as the latter have a stronger communal dimension than the former (Yang 2011; Sun 2014).

Other variables include village socioeconomic development. Education is measured by the proportion of villagers with at least some high school education. Village per capita annual income reflects the level of resources that may shape people's need and willingness to participate in collective resistance. Per capita fiscal transfer from upper-level government indicates village collective resource endowments and the degree of its financial reliance on local government. To take account of land scarcity and susceptibility to climatic shocks, we control for per capita household farmland and the proportion of village arable land that is irrigated. For village economic structure, we include the number of private-owned enterprises and the proportion of 
village population working exclusively in the agricultural sector. We also adjust for whether anyone from the village currently works in the upper-level government, which provides a source of political capital.

Measures of village population composition include population size, the proportion of ethnic minorities, and the proportion of working-age population (age 16-60; a proxy for population age structure). Another important control is the proportion of working-age population that migrated outside the village for work. They may bring new political attitudes and behaviors to the village or undermine community solidarity for collective action.

\section{Methods}

The unit of analysis is the administrative village. We pooled village-level data from 2004 through 2008. This longitudinal design allows us to reduce potential biases and obtain more reliable results. A main source of bias occurs when village contextual factors (e.g., village history, culture of social and civic engagement, or the quality of local governance) give rise to both a village's organizational sphere and collective resistance. The bias inflates the positive role of social organizations. We used longitudinal fixed-effects models to adjust for potential confounding factors that are constant over time. There may also be time-varying factors associated with both village organizational environments and collective resistance. We adjust for some of these changing conditions by including a rich set of time-varying variables (including land requisition) and year dummy variables. 
In the sample villages, virtually all seniors associations and religious organizations were established before 2004, the first year of observation. The same is true for village lineage network structures, as they are the product of many decades of evolution. These measures are thus time-invariant over the study period. By design, time-invariant variables are dropped in the fixed-effects models. An identification strategy is to interact these time-invariant variables with time-varying variables (Allison 2009; Wooldridge 2010). Following this common practice, we include interactions between social organizations and land requisition (time-varying). This enables us to examine the role of these organizations in collective resistance as triggered by local grievances related to land requisition, while conditioning out some endogenous factors in the village. $^{11}$

The fixed-effects linear probability model is formulated as:

$$
P\left(y_{i t}=1 \mid x\right)=\mu_{t}+\alpha_{i}+\beta \times L_{i t}+L_{i t} \times \boldsymbol{O}_{i} \boldsymbol{\Gamma}+\boldsymbol{X}_{i t} \boldsymbol{\Delta}
$$

where $y_{i t}$ is the occurrence of collective petition (or protest) for village $i$ in year $t ; \mu_{t}$ is the intercept; $L_{i t}$ indicates land requisition in village $i$ in year $t ; \boldsymbol{O}_{i}$ is a vector of village organizations (i.e., seniors association, lineages); and $\boldsymbol{X}_{i t}$ is a vector of control variables. Importantly, $\alpha_{i}$ represents the fixed effects specific to each village but constant over time, which effectively adjusts for time-invariant unobserved factors specific to each village. We can also use logit models with fixed-effects. But these models drop villages experiencing no change in the

\footnotetext{
${ }^{11}$ The main effect of social organizations is not of primary interest. In theory, the presence of these organizations alone would not automatically translate into collective action. They become important forces only in the presence of local crisis that provokes widespread grievances (i.e., land requisition).
} 
occurrence of collective resistance over time ( $45 \%$ villages in the data). This would result in a selected sample and undermine the accuracy of our estimates. In this situation, a linear probability fixed-effects model is an effective approximation of the underlying probability for discrete-choice data (Wooldridge 2010).

To examine the success of collective petitions, we first conducted logistic regression analysis at the event (petition) level, controlling for the same set of village-level variables and a variable indicating the size of petition. We corrected the standard errors for clustering of petitions at the village level. Furthermore, we carried out a village-level analysis using two-stage Heckman selection estimation (Heckman 1979), to take into account the fact that petition outcomes were observed only in villages where they occurred. We first modeled the likelihood of any collective petition in a village in a given year using the same set of variables in estimating petition occurrence. In the second-stage regression, we estimated whether any petition in the village in a given year was successful, controlling for the likelihood that collective petition occurred and other factors that could be associated with petition success (similar explanatory variables except for those measuring land conditions, which are used to identify the model).

\section{DESCRIPTIVE STATISTICS}

The distribution of collective petitions and protests by province over the study period is displayed in Appendix B. Despite some regional variations, collective resistance occurred in all provinces. Petitions were more common than protests. 
Figure 1 shows over-time change. Collective petitions with a small number of complainants have grown over time. For large-scale petitions with more than 50 complainants, the change is stagnant. This may result from government's effort to contain large-scale petitions. The drop in 2008 is because petitions that occurred after the 2008 survey were not recorded. The number of protests has also grown over time (Figure 2), except for 2008. Unlike petitions, protests with more than 30 or 50 participants have increased between 2005 and 2007, reflecting the greater difficulty local governments face in containing non-institutionalized forms of collective action.

[Figure 1 and 2 about here]

Table 2 shows the descriptive statistics in the first and last year of observation (2004 and 2008). Over the study period, the percentage of villages experiencing collective petitions increased from $16 \%$ to over $21 \%$. The corresponding change for protests and land requisition is respectively, $8.8 \%$ to $10.6 \%$, and $10.6 \%$ to $13.2 \%$. With respect to the village organizations, about $35.4 \%$ of the villages have a seniors association, which turns out to be the most prevalent

rural association and appears across all provinces. As for lineage structure, $28.3 \%$ and $27.4 \%$ of the villages are monopolistic and oligopolistic, respectively. Descriptive statistics for other variables are discussed in Appendix C.

[Table 2 about here]

\section{RESULTS OF COLLECTIVE RESISTANCE OCCURRENCE}


Table 3 presents results of the occurrence of collective petitions. Model 1 is the baseline model, which shows a positive coefficient of land requisition and suggests that it is a trigger for collective resistance. After introducing the interaction terms in subsequent models, land requisition is no longer significant. These results underscore the importance of rural organizations: land requisition alone is not a sufficient condition; rather, the emergence or quiescence of collective resistance requires an organizational basis.

Models 2 to 4 lend strong support to the importance of social organizations in rural contention, albeit in distinct ways. When there are local grievances triggered by land requisition, the presence of a semi-autonomous seniors association significantly and consistently reduces the onset of collective petition of various scales.

[Table 3 about here]

The in-depth interviews corroborate the quantitative results. In our interviews, a recurring theme is the popular support and government connections of seniors associations. In emphasizing the prestige and mass support enjoyed by the association, one village head in Jiangsu Province said: "The past and present leaders of the seniors association are retired cadres from the county and town. Their role is important. Before they took charge of the association, they already have a great deal of prestige and credibility... They have strong mass support." Such a mass base affords seniors associations strong bonding social capital, which originates from associational ties among members of the association and extends to the rest of the community through the social networks of the elderly and their personal prestige. In this way, the 
seniors association has the capacity to bridge different social groups in the village, mobilizing them to achieve common goals when needs arise, and link them with the state.

Acknowledging the importance of the association, local governments consciously cultivate relations with the associations. As the village head went on to explain: "The presence of the seniors association is good for us to carry out our work. County and township officials also hope to use the association to place retired officials. This way they are able to use old people's authority to solve problems in the village and help them carry out work. When land requisition and other government policies are enforced in the village, village and township governments often rely on the seniors association to persuade villagers." This strategy is built on the vertical linkages of the association. Our data show that the majority of seniors associations in our sample (92\%) were set up by different levels of governments, and $85 \%$ of the leaders are retired cadres or retired teachers. This background allows the association to forge linkages with the government through personal or institutionalized channels. These government connections are further formalized and institutionalized in the process of working with local officials.

The distinct qualities of seniors associations confer special importance in collective resistance, giving villagers a legitimate voice while convincing them to contain their grievances. Noting the mediating role of seniors associations in state-society conflicts, a villager in Fujian Province commented: "During a recent land requisition, the local government asked the seniors association to assist in circulating information and persuading villagers. At the same time, the association came forward to represent aggrieved villagers who had planned to petition, and negotiate proper compensations with township officials and land developers. They solicited 
requests put forward by local residents and used them in the negotiation. They identified villagers with great financial difficulties and coordinated with the government and land developer to offer these families greater compensation... The seniors association asked the villagers not to petition during the negotiation. The association was a good mediator. Both sides were willing to listen to them. The outcomes are usually quite good when the seniors association negotiate. Local governments also fear that they might organize collective petitions." As such, a mediation channel that reinforces the vertical linkages is institutionalized. Indeed, the threat of mobilization is an effective strategy for the seniors association to extract concession from local officials. When the seniors association negotiated terms with authorities, officials were aware that they represented and were backed by the entire village and that failing to reach a satisfactory resolution they may deploy collective action.

The foregoing example, together with other instances of suppressed contentions that surfaced in the interviews, demonstrates how seniors associations serve as an effective vehicle of interest intermediation between state and societal actors. These associations construct a cooperative relationship with the local state, effectively resolving local problems while suppressing tensions from escalating into collective resistance. These preemptive local solutions are mutually beneficial, more so than higher-level interventions in resolving state-society disputes (Michelson 2008). For local authorities, mediation appeals to their moral authority and strong imperative to maintain social stability. They deem the associations to be legitimate and credible negotiation partners given their semi-official status. For villagers, local solutions are preferable because they yield faster and effective resolution at lower costs. 
Likewise, lineage networks matter. As shown in Table 3, villages with an oligopolistic structure are more likely than mixed-surname villages to experience collective petitions when facing land requisition. Monopolistic villages, enjoying a high degree of cohesiveness, are more likely to experience large-scale petitions (more than 50 claimants), but not small or medium-size petitions, than mixed-surname villages.

Our field notes are replete with examples of how a highly fragmented lineage structure in mixed-surname villages is detrimental to collective mobilization. As one villager in Hebei province put it: "My village is a mixed-surname (zaxing) village. There is no ancestral hall. The notion of kinship ties is not strong. Each family just minds its own business... The village is like a plate of loose sand (yipan sansha)... Several years ago, part of our farmland was taken to build a road. We received no compensation at all. Villagers were all very angry. But nobody organized petitions. Actually, there has never been a collective event in the village."

By contrast, in villages with strong lineage networks, group solidarity provides solid grounds for mobilization. We encountered many reports of village unity in such villages. A villager in Jiangsu Province said: "There have been several collective petitions in the village... When the interest of the lineage is harmed, prestigious people in the lineage speak up. And after they do, the rest of the lineage responds and spontaneously (zifa) organizes itself. Petitions are just easily organized here.” The villager further elaborated how regular lineage social gatherings became the setting where planning and action took place. As an informal rule, each household in the lineage would send a representative to these gatherings, which naturally became meetings to discuss the issues, make plans to petition, and subsequently sign petition papers. In north China 
where lineages are not as widespread or as formally organized as in south China, lineages are nevertheless present and in some villages become important units of social organization (Cohen 2005; Campbell and Lee 2011). A villager explained that in a Jilin village: "Here everyone gets along with each other. If someone in the lineage organizes something, he doesn't need to convince (shuifu) other people to participate. People just join.” Even in villages where the power of lineage seems latent, lineage-based solidarity can be reactivated in times of crisis.

The interviews identify another mechanism for lineage-based collective resistance. In addition to intra-lineage solidarity, social divisiveness between large lineages can further trigger collective action. Oligopolistic villages often have a long history of conflict between major lineages. This is especially likely if one lineage is overrepresented in the village committee, and the village cadres use their positions to benefit their own lineages. In this context, land-related issues can intensify existing inter-lineage disputes over scarce resources, motivating the less dominant lineages to draw on their intra-lineage solidarity to stage collective action. In Sichuan Province, for example, a highway construction project affected a village with two large lineages, causing conflicts between them regarding the distribution of land and compensation. One lineage challenged the village cadres about inequity in allocation and compensation standards. This subsequently led to collective petitions against questionable allocation of benefits and charges of embezzlement against the village head.

Overall, the results highlight how collective resistance is shaped by both intra-lineage cohesion and inter-lineage conflicts. They help explain why collective resistance is most prevalent in oligopolistic villages. In a way, the results reiterate the commonly recognized 
importance of internal structure, and identify distinct forms and mechanisms through which it shapes collective action. Beyond the internal structure typically conceptualized in the literature as a high degree of horizontal solidarity, we find that a combination of solidarity (intra-clique horizontal linkages) and fragmentation (inter-clique tensions) can be equally, if not more, conducive to collective mobilization. To be sure, collective action in oligopolistic villages often, but not always, arises from inter-lineage conflicts. Different lineages are sometimes brought together around the same issues that affect community-wide interest. In these situations, intralineage cohesion can combine with a common threat to forge large-scale contention.

Regression results of religious organizations suggest that temples are not significantly related to the occurrence of petitions, but the presence of churches is positively related to petitions. We are hesitant to draw conclusions about the direct importance of churches in collective action, however, because both our in-depth interviews and research (Xing 2003; Yang 2011) suggest the opposite. It is more plausible that the positive coefficient results from a social process in which churches provide public space in rural China that helps forge social capital, which can then be activated for collective action. A detailed discussion is in Appendix D.

Table 4 displays the results for protests. The main findings are consistent with those for petitions. First, the presence of seniors associations reduces protests, especially those involving more than 30 and 50 participants. Second, protests are more likely to occur in villages with strong lineage networks (monopolistic or oligopolistic structure) than in mixed-surname villages. 
Similar to petitions, monopolistic villages are especially likely to experience medium and largescale protests. ${ }^{12}$

[Table 4 about here]

Comparing Tables 3 and 4, lineage network structures are more consistently associated with protests than with petitions most likely because the cohesive lineage networks are especially crucial for mobilization for high-risk contentions (i.e., non-institutionalized contentions). In addition, the role of seniors associations is somewhat more prominent in containing institutionalized petitions than protests, presumably because protests occur more spontaneously and spread more rapidly than formal petitions, thus increasing the difficulty of mediation.

\section{RESULTS OF SUCCESS OF COLLECTIVE PETITION}

Table 5 displays the results of the success of collective petitions. Model 1 is based on all 254 collective petition cases in the sample villages from 2004 through 2008. Among them, 29.8\% achieved some degree of success. Model 2 is based on a two-stage model of petition success, conditional on its occurrence in the village. In both models, the presence of seniors associations is positively related to petition success, but lineage networks show no such relation. ${ }^{13}$

\footnotetext{
${ }^{12}$ The relationships between other variables and collective action in Table 3 and 4 are generally unclear. This underscores the importance of organizations in rural resistance.

${ }^{13}$ Because petition cases may drag on for some time before reaching a definite resolution, the data may not fully capture the ultimate petition result. Our research design is less sensitive to the possible time lag because information on collective action was gathered retrospectively in the 2008 wave. We further conducted a sensitivity analysis dropping petitions that were submitted in 2007 and 2008 and that did not reach a resolution by the end of the survey period (a total of 62 petitions). The results are similar to those presented in the Table 5 (coefficient is 0.925 ; standard error is 0.367 ). The coefficient of seniors
} 
[Table 5 about here]

The fieldwork provided insights into the adaptive role of seniors associations in collective resistance. When mediation fails to yield results, seniors associations can reconstruct a competitive relationship with the state by mobilizing collective petitions. This is in part attributable to the mass support and high degree of autonomy they enjoy. ${ }^{14}$ In a Fujian village, compensation for land requisition failed to reach villagers after multiple rounds of negotiations led by the seniors association. As grievances grew, villagers urged the association to organize a collective petition. The association took the lead and organized petitions with over 30 petitioners directed to the township and county governments. Eventually, the village received compensation payments of more than 300,000 yuan. In another village, the main contention involved corrupt village cadres who mismanaged funds from land sales. Seeing that villagers failed to receive their rightful share of compensation, the seniors association met with the village cadres to claim appropriate compensations on behalf of villagers. After several unsuccessful attempts, the association launched a collective petition, which finally brought down the village head and party secretary on corruption charges, signed by 80 villagers.

Why did seniors associations facilitate the success of collective petitions? A village cadre explained that the corruption of his predecessors over land sales would not have been exposed if

associations becomes even slightly larger, pointing to the possibility that seniors associations facilitate petition success not only generally but also in a more timely manner.

${ }^{14}$ Our data show that most seniors associations in our sample (over 88\%) received little or no government funding and primarily resorted to other sources of funding, including selling or leasing collectively owned assets, donations, and membership fees. The fiscal independence allows them to retain a high degree of operational autonomy. 
not for the seniors association: "Ordinary villagers would not know much about the affairs involving village leaders and how they may violate the law. Even if they did find out, they would not be able to gather useful evidence that is possible to bring down the cadres... Leaders of the association are knowledgeable and experienced. They collected useful evidence... Key members of the association have good connections with the township government. The township government paid attention to the case. During the petition, the association was able to maintain updated information on the petition and act accordingly. They certainly had some influence on the direction of the petition."

A key member of the association, and a major player in the case, added in a follow up interview: "Of course it is best to solve the problems without petitioning. But sometimes it doesn't work. In this case, my association had to come forward to represent the village and petition. I have some relationships with the township government, because I previously worked there and because they often ask my association to help with their work in the village. So they usually take our requests quite seriously." Through these connections with higher-level officials, he had better information about effective tactics. He could gather land requisition documents and evidence that did not reach peasants regarding the transfer of funds to the village. Also, whereas most petitioners are barred from entering the main government building, township officials received him and other association members and allowed them to present the petition in person to officials, who agreed to conduct a timely investigation. During the investigation, he actively monitored the progress and helped expedite a decision. They eventually succeeded in disciplining the corrupt village cadres. 
These cases illustrate the substantial adaptability of seniors associations, which allows them to safeguard community interests by combining, at different times, orderly negotiation with mass mobilization. When the circumstances induce the associations to turn to collective action, they benefit from their organizational legitimacy and, more important, from the vertical linkages with local governments to press strong claims. These linkages can be established through the association's formal relationship with authorities or through the pre-existing social relations of members who previously held government positions. In either case, the linkages become formalized in the association's structure and help the association navigate bureaucratic processes and obtain support from within the state.

Furthermore, our in-depth interviews point to constraints faced by lineage groups in collective resistance. Despite the importance of lineages in collective mobilization, these collective actions often do not bear fruit. In the interviews, there was no discussion of the way lineages facilitate contention success. Rather, a common theme is how lineage groups have become increasingly disengaged from local politics given their tenuous relations with state authorities. A villager in Jilin province explained: "The heads of the lineages are quite indifferent to politics. They do not have the guts to press issues with higher-level governments... You really need someone to press hard. Just sending petition materials is not enough. They will ignore you." Another interview with a lineage head in Sichuan Province reiterated the limitations facing lineage groups: "We do not have people in the higher-up [township and county governments]. They are not very responsive to our petition. The petition led to nothing (buliao liaozhi). Petitions are useless, if you don’t have people in the higher-up (shangmian meiren).” 
Local authorities also perceive different organizations differently. A township official in Jiangsu Province noted: "The seniors association is a formal and outward (duiwai) organization. It assists our work in local areas. Lineages are different. They are inward (duinei) organizations for their members." As such, local authorities accept seniors associations as sanctioned, credible organizations that represent community-wide interests and engage in reciprocal relationships with local authorities. Officials are more likely to sympathize with the association. Their working relation with the state gives the association additional institutional leverage in extracting concessions from the state. In contrast, lineage groups are viewed as parochial organizations concentrating on lineage interest. Given this distinction, petitions organized by lineages are perceived with suspicion, sometimes even as a threat, and less likely to be treated favorably. As the official stated: "Petitions forwarded by lineages are usually due to conflicts between lineages or between sublineages. We usually don't handle these cases. We order village cadres to solve their problems. In some occasions, lineage heads incite masses of the lineage to petition and gather around government agencies. This affects social order and interferes with our orderly operation. We firmly oppose this action."

These results demonstrate the political milieu that has served to undermine the power of lineages beyond the village level. Lineages lack the political legitimacy and vertical linkages that are required to obtain official support. Also, many gradually grow into parochial groups and shy away from pressuring state authorities for redress. As a result, collective petitions orchestrated by lineages tend to be rebuffed.

\section{CONCLUSION AND DISCUSSION}


The present study examines the role of social organizations with distinct structural characteristics in the occurrence and success of collective action in rural China. We focus on informal lineage groups and semi-autonomous seniors associations, which have strong horizontal linkages within their constituencies but are embedded in disparate external structures. As a result, they play fundamentally distinct roles in collective action. Semi-autonomous seniors associations act as intermediaries between the government and aggrieved citizens, addressing local grievances through mediation and largely suppressing the occurrence of collective resistance. But when mediation fails and collective action emerges, the association can exploit its vertical linkages to the state to facilitate successful action. In contrast, lineages serve as solidarity groups and mobilizing structures for collective resistance, taking the place of formal mobilizing structures that are absent in rural China. Once collective petitioning is underway, however, lineage groups, owing to their informal status and weak vertical linkages with the state, face considerable limitations in exerting political influence beyond the village and achieving success, at least with respect to institutionalized contentions.

This study adds to the social movement literature in several ways. First, it contributes to a more nuanced understanding of the structural embeddedness of organizations, especially the less systematically examined external structure of varied vertical linkages between organizations and state actors. Focusing on vertical linkages enables us to move beyond the debate on whether organizations facilitate or impede collective action, which presumes that organizations affect movements in the same manner, to uncover a more complex relationship between varied organization forms and contention. It also allows us to identify which type of organizations can be converted into instruments for mobilization and which type acts as "counter-mobilizing 
structures" to suppress imminent collective action. Once collective action begins, organizations with different external structures are set on diverse paths: some are constrained and become more conservative while others are bolstered by the vertical linkages to achieve success. These findings emerge from a research design that incorporates diverse settings, including those where collective action erupts and where it fails to emerge, and that studies success conditional on collective action emergence.

The organizational structures examined here extend the conceptualization of strong versus weak ties and bonding versus bridging ties (Granovetter 1973; Putnam 1993) to the study of collective action. The horizontal linkages we defined represent strong, bonding ties, whereas the vertical linkages manifest a form of weak bridging ties that connect the societal and state side of collective action. As the findings show, collective action turns not only on strong bonding ties that mobilize. To a large degree, its emergence and success is also shaped by weak bridging ties. In this respect, our study offers a new understanding of the "strength of weak ties" (Granovetter 1973) but in a different mechanism. Rather than serving mainly as conduits of information, weak bridging ties can function as a source of political influence.

This research's second contribution is to examine both the occurrence and success of collective action in a unified framework, rather than in separate investigations. It generates a more dynamic understanding of organizational conditions in contention. In particular, it elucidates the distinct role of different types of organizations in different stages of collective 
action, which are missed in studies focusing only on movement onset or success. ${ }^{15}$ A high degree of vertical linkages may prevent grievances from escalating into outright mobilization in the near term, but they can be transformed into critical political assets for contention when grievances remain unresolved. This finding underscores the importance of going beyond a dichotomous conceptualization of vertical linkages (integrated vs. autonomous) to investigate organizations with a hybrid structure (semi-autonomous). These hybrid organizations oscillate between multiple mechanisms of influence (i.e., orderly mediation vs. mass mobilization) to accomplish targeted goals.

Third, the present study contests the conventional view that an effective organizational basis for collective action is absent in non-democratic societies. We link the often separate literature on popular contention and civil society in these settings, and demonstrate that social organizations play a greater and more intricate role in contentious politics than previously conceived - a diverse spectrum of social organizations co-exists and performs distinct roles. The relationship between organizations and contentions in non-democracies exhibits several distinctions from democratic settings. Because formal movement organizations are absent, a process of social appropriations takes place (McAdam 2002), in which social organizations created for non-movement purposes are redefined as sites for mobilization or countermobilization. In non-democratic settings, vertical linkages are especially crucial. They provide organizations and their constituencies unusual access to the political process, sometimes without

\footnotetext{
${ }^{15}$ The present study has several limitations, especially for the analysis of collective action success. The data do not provide information on indirect outcomes of collective action that would allow us to assess its broader influence. Also, we have no data on the success of non-institutionalized collective resistance (i.e., protests) and thus are unable to systematically examine similarities and differences in the organizational conditions for different forms of collective action.
} 
taking their grievances to the streets. We identify a preemptive mechanism, in which mediation, rather than cooptation, is carried out by social organizations with mediating capacity. This preemptive mechanism contrasts with limited state intervention in initial contention in democratic regimes, although sustained movements may invoke subsequent state strategies. Failure of initial mediation can lead to more contentious tactics. In this context, neither the societal groups nor the state-corporatist organizations are the most vital players in local politics. Semi-autonomous and semi-official civic associations in between state patronage and civil society models are an especially prominent social force.

The political significance of semi-autonomous civic associations deserves special attention. They remain a rare and inadequately understood resource in non-democracies considering the complexity in maintaining both state connections and organizational autonomy. Nevertheless, these associations inhabit an intermediary space between state and society. They are not simply vehicles for cooperating with or opposing the local party-state. They represent a separate sphere of political power with considerable adaptability in which they construct relations with the state through oscillations between cooperative and competitive interactions. In the latter scenario, they can exploit their vertical linkages and familiarity with the polity to counterbalance the system when needs arise.

The strategy of combining cooperation (mediation) with competition (contention) strengthens the associations' political importance. On the one hand, mediation not only helps the aggrieved obtain timely and desired solutions but also serves the state's imperative to maintain social stability. Recognizing them as legitimate intermediaries, the state has consciously 
cultivated working relationships with seniors associations, allowing associations to negotiate for autonomy and access state actors. A high degree of autonomy protects the association from cooptation and being forced from their original goals. On the other hand, when semi-autonomous associations enter into competitive relations with the state through contentious tactics, they are often able to extract concessions from local authorities, who have come to depend on the associations for solving local disputes. Such successes allow associations to sustain a high level of mass support and bolster the association's bargaining power in mediation since state officials know that without concessions associations may turn to mobilization. ${ }^{16}$

Our empirical study focuses on rural China. It also has direct relevance for understanding the relationship between civil society and collective action in urban China, which has witnessed an explosion of civil society organizations (Gallagher 2004). There is a growing sector of urban NGOs oriented toward social service delivery. Some are registered by the state but at the same time retain operational autonomy (Teets 2013). Although not completely independent from the state, they work effectively, sometimes in strategic collaboration with the state, to address social needs that may fuel grievances. This results in a symbiotic relationship between the local state and these NGOs (Spires 2011). By mediating local state-society conflicts to prevent local problems from flaring up, these urban NGOs are positioned to assume a role similar to semiautonomous associations in rural China. In so doing, they may be granted more legitimacy, greater institutionalized access to decision makers, and more power in negotiating with the state for autonomy. Yet there are differences in the dynamics of collective action in urban areas,

\footnotetext{
${ }^{16}$ Semi-autonomous associations tend to display considerable resilience. Local governments have occasionally tried to rein in seniors associations, with limited effect (Deng and Ruan 2006). Local officials have come to depend on the associations for interest mediation, and blocking the power of the associations risks triggering escalated collective resistance.
} 
where society is more atomized and lacks effective indigenous organizations. As such, mobilizing structures are based on temporary communities formed around working and living space (and increasingly online space). In this respect, collective action tends to be more spontaneous and to spread faster (Solinger 2009), which increases the difficulty of mediation. The relationship between urban social organizations and collective action presents a promising direction for research.

Based on our findings, it may seem logical for the state to embrace the idea of promoting the development of semi-autonomous civic associations for better local governance and social stability. The unique status of these associations, however, presents a real dilemma, which hinders the state from building effective social foundations for a healthy society. The authoritarian state continues to dread civic organizations, especially those with resilience and broad-based support (Saich 2000), even though most rarely press for democratic claims. Rapid, unconstrained growth of civic associations, especially if leading to de-cellularization and scaling up that foster translocal coalitions, undercuts authoritarian power in local society, which the Party is unwilling to tolerate. In recent years the Party has narrowed the room in which social organizations operate. This strategy, rather than yielding the intended result, lands the state in a predicament - social protests have risen instead of declined, even in places that face aggressive crackdowns on social organizations. In the absence of a local mediating institution for resolving disputes, a precarious mode of political stability may develop. Previous research has found a form of collusion between local governments and crime syndicates in rural China, which contains popular resistance through violent means rather than addressing official malfeasance 
(Hurst et al. 2013). This mechanism of social control can harm state-society relations in the longterm, making the regime particularly vulnerable to citizen grievances.

Although the evidence is drawn from China, the conceptual and analytic framework developed here can inform studies of collective action in general. Attention to the degree of organizations' vertical linkages, coupled with a design that includes both contentious and quiescent settings as well as different stages of collective action, will unveil a more fine-grained understanding of the role of social organizations than previously documented. Our framework is not limited to but may be especially relevant for non-democratic settings. These societies are likely to share with China a growing civil society and an intricate field of interactions between state and societal forces. Further research can provide a wealth of insight by comparing the roles and strategies of a diverse organizational sphere. 


\section{REFERENCES}

Allison, Paul D. 2009. Fixed Effects Regression Models. Thousand Oaks: SAGE publications. Amenta, Edwin, Bruce G. Carruthers, and Yvonne Zylan. 1992. "A Hero for the Aged? The Townsend Movement, the Political Mediation Model, and US Old-Age Policy, 19341950." American Journal of Sociology 98(2): 308-39.

Amenta, Edwin, Neal Caren, and Sheera Joy Olasky. 2005. "Age for Leisure? Political Mediation and the Impact of the Pension Movement on US Old-age Policy." American Sociological Review 70(3): 516-538.

Andrews, Kenneth T. 2001. "Social Movements and Policy Implementation: The Mississippi Civil Rights Movement and the War on Poverty, 1965 to 1971." American Sociological Review 66(1): 71-95.

Avritzer, Leonardo. 2002. Democracy and the Public Space in Latin America. Princeton, NJ: Princeton University Press.

Bernstein, Thomas P., and Xiaobo Lü. 2008. Taxation without Representation in Contemporary Rural China. New York: Cambridge University Press.

Cai, Yongshun. 2010. Collective Resistance in China: Why Popular Protests Succeed or Fail. Redwood City, CA: Stanford University Press.

Campbell, Cameron, and James Z. Lee. 2011. "Kinship and the Long-term Persistence of Inequality in Liaoning, China, 1749-2005." Chinese Sociological Review 44(1): 71-103.

Chan, Chris King-Chi, and Pun Ngai. 2009. "The Making of a New Working Class? A Study of Collective Actions of Migrant Workers in South China." The China Quarterly 198: 287-303.

Chen, Xun. 2012. "How is Rural Social Power Possible? Research on Seniors Association in Wenzhou." Chinese Rural Survey 1: 80-88.

Chen, Yi. 2008. "Collective Petitioning and Institutional Conversion." Pp. 54-70 in Popular Protest in China, edited by Kevin J. O’Brien. Cambridge, MA: Harvard University Press.

Clemens, Elisabeth S. 1996. "Organizational Form as Frame: Collective Identity and Political Strategy in the American Labor Movement, 1880-1920.” Pp. 205-26 in Comparative Perspectives on Social Movements, edited by Doug McAdam, John D. McCarthy, and Mayer N. Zald. New York: Cambridge University Press.

Cloward, Richard A. and Frances Fox Piven 1984. "Disruption and Organization: A Rejoinder." Theory and Society 13: 587-99.

Cohen, Myron L. 2005. Kinship, Contract, Community, and State: Anthropological Perspectives on China. Redwood City, CA: Stanford University Press.

Cress, Daniel M., and David A. Snow. 2000. "The Outcomes of Homeless Mobilization: The Influence of Organization, Disruption, Political Mediation, and Framing." American Journal of Sociology 105(4): 1063-1104.

Della Porta, Donatella, Hanspeter Kriesi, and Dieter Rucht. 2009. Social Movements in a Globalizing World. $2^{\text {nd }}$ ed. Basingstoke: Palgrave Macmillan.

Deng, Yanhua, and Hengfu Ruan. 2006. "Gray Power in Rural China: A Case Study of Seniors Associations in Zhejiang." Sociological Studies 8: 131-54.

Diani, Mario, and Doug McAdam, eds. 2003. Social Movements and Networks: Relational Approaches to Collective Action: Relational Approaches to Collective Action. New York: Oxford University Press.

Ding, Xueliang. 1994. "Institutional Amphibiousness and the Transition from Communism: The Case of China." British Journal of Political Science 24(3): 293-318. 
Evans, Sara Margaret. 1979. Personal Politics: The Roots of Women's Liberation in the Civil Rights Movement and the New Left. Vol. 228. New York: Random House.

Feng, Erkang. 2009. History of Lineage in China. Shanghai People's Press.

Fox, Janice Langan, and Cary Cooper. 2013. Boundary-spanning in Organizations: Network, Influence and Conflict. New York: Routledge.

Gallagher, Mary. 2004. "China: The Limits of Civil Society in a Late Leninist State." Pp. 419-52 in Civil Society and Political Change in Asia: Expanding and Contracting Democratic Space, edited by M. Alagappa. Stanford, CA: Stanford University Press.

Gamson, William A., and Emilie Schmeidler. 1984. "Organizing the Poor." Theory and Society 13: $567-85$.

Gamson, William A. 1990. The Strategy of Social Protest. $2^{\text {nd }}$ ed. Belmont, CA: Dorsey Press.

Ganz, Marshall. 2000. "The Paradox of Powerlessness: Leadership, Organization, and Strategy in the Unionization of California Agriculture, 1959-77." American Journal of Sociology 105:1003-62.

Giugni, Marco G. 1998. "Was It Worth the Effort? The Outcomes and Consequences of Social Movements." Annual Review of Sociology 24: 371-93.

Giugni, Marco G., and Sakura Yamasaki. 2009. "The Policy Impact of Social Movements: A Replication through Qualitative Comparative Analysis.” Mobilization 14(4):467-84.

Granovetter, Mark S. 1973. "The Strength of Weak Ties." American Journal of Sociology 78(6): 1360-1380.

Guo, Xiaolin. 2001. "Land Expropriation and Rural Conflicts in China." The China Quarterly 166:422-39.

Hansen, Mette Halskov. 2008. "Organising the Old: Senior Authority and the Political Significance of a Rural Chinese 'Non-Governmental Organisation'.” Modern Asian Studies 42(5): 1057-78.

He, Xuefeng. 2003. New Rural China. Nanning: Guangxi Normal University Press.

Heckman, James J. 1979. "Sample Selection Bias as a Specification Error." Econometrica: Journal of the Econometric Society 47(1): 153-61.

Howell, Jude. 2007. "Civil Society in China: Chipping Away at the Edges." Development 50(3): 17-23.

Huang, Philip C. 2008. "Centralized Minimalism Semiformal Governance by Quasi Officials and Dispute Resolution in China." Modern China 34(1): 9-35.

Hurst, William, Mingxing Liu, Yu Liu, and Ran Tao. 2013. "Reassessing Collective Petitioning in Rural China: Civic Engagement, Extra-State Violence, and Regional Variation." Comparative Politics 46:459-482.

Kennedy, John James. 2002. "The Face of 'Grassroots Democracy' in Rural China: Real Versus Cosmetic Elections." Asian Survey 42(3): 456-82.

Kennedy, John James. 2007. "From the Tax-for-fee Reform to The Abolition of Agricultural Taxes: The Impact on Township Governments in North-West China." The China Quarterly 189: 43-59.

Koopmans, Ruud, and Dieter Rucht. 2002. "Protest Event Analysis." Methods of Social Movement Research 16: 231-59.

Kriesi, Hanspeter. 1996. "The Organizational Structure of New Social Movements in a Political Context." Pp. 152-84 in Comparative Perspectives on Social Movements, edited by Doug McAdam, John D. McCarthy, and Mayer N. Zald. New York: Cambridge University Press. 
Lee, Ching Kwan. 2007. Against the Law: Labor Protests in China's Rustbelt and Sunbelt. Berkeley and Los Angeles: University of California Press.

Lee, Ching Kwan, and Yonghong Zhang. 2013. "The Power of Instability: Unraveling the Microfoundations of Bargained Authoritarianism in China." American Journal of Sociology 118(6): 1475-1508.

Li, Lianjiang, and Kevin J. O'Brien. 2008. "Protest Leadership in Rural China." The China Quarterly 193: 1-23.

Lin, George, and Samuel Ho. 2005. "The State, Land System, and Land Development Processes in Contemporary China." Annals of the Association of American Geographers 95(2): 411436.

Liu, Liangqun, and Rachel Murphy. 2006. "Lineage Networks, Land Conflicts and Rural Migration in Late Socialist China." Journal of Peasant Studies 33(4): 612-45.

McAdam, Doug. 1982. Political Process and the Development of Black Insurgency, 1930-1970. Chicago: University of Chicago Press.

McAdam, Doug. 2003. "Beyond Structural Analysis: Toward a More Dynamic Understanding of Social Movements," in Mario Diani and Doug McAdam, eds. Social Movement Analysis: The Network Perspective. New York: Oxford University Press.

McAdam, Doug, Sidney Tarrow, and Charles Tilly. 2001. Dynamics of Contention. New York: Cambridge University Press.

McCarthy, John D., and Mayer N. Zald. 1977. "Resource Mobilization and Social Movements: A Partial Theory." American Journal of Sociology 82(6): 1212-41.

McCarthy, John D. 1996. "Constraints and Opportunities in Adopting, Adapting, and Inventing." Pp. 141-51 in Comparative Perspectives on Social Movements, edited by Doug McAdam, John D. McCarthy, and Mayer N. Zald. New York: Cambridge University Press.

Michels, Robert. 1962 [1915]. Political Parties: A Sociological Study of the Oligarchical Tendencies of Modern Democracy. New York: Collier Books.

Michelson, Ethan. 2007a. "Lawyers, Political Embeddedness, and Institutional Continuity in China's Transition from Socialism1." American Journal of Sociology 113(2): 352-414.

Michelson, Ethan. 2007b. "Climbing the Dispute Pagoda: Grievances and Appeals to the Official Justice System in Rural China." American Sociological Review 72(3): 459-85.

Michelson, Ethan. 2008. "Justice from Above or Below? Popular Strategies for Resolving Grievances in Rural China." The China Quarterly 193: 43-64.

Minkoff, Debra C. 1999. "Bending with the Wind: Strategic Change and Adaptation by Women's and Racial Minority Organizations." American Journal of Sociology 104(6): 1666-1703.

Minkoff, Debra C., and Walter W. Powell. 2006. "Nonprofit Mission: Constancy, Responsiveness, or Deflection?" in Powell W.W., Steinberg R. (eds), The Nonprofit Sector: A Research Handbook (2 ${ }^{\text {nd }}$ edition), pp. 591-611. New Haven, CT: Yale University Press.

Minzner, Carl F. 2006 "Xinfang: An Alternative to Formal Chinese Legal Institutions." Stanford Journal of International Law 42: 103.

Morris, Aldon D. 1984. The Origins of the Civil Rights Movement: Black Communities Organizing for Change. New York: Free Press.

Murphy, Rachel, Ran Tao, and Xi Lu. 2011 "Son Preference in Rural China: Patrilineal Families and Socioeconomic Change." Population and Development Review 37(4): 665-690.

O’Brien, Kevin J., and Lianjiang Li. 2006. Rightful Resistance in Rural China. New York: Cambridge University Press. 
O'Donnell, Guillermo, and Philippe C. Schmitter. 2013. Transitions from Authoritarian Rule: Tentative Conclusions about Uncertain Democracies. Baltimore, MD: Johns Hopkins University Press.

Oberschall, Anthony. 1973. Social Conflict and Social Movements. Englewood Cliffs, NJ: Prentice-Hall.

Osa, Maryjane. 2003. Solidarity and Contention: Networks of Polish Oppositions. Minneapolis: University of Minnesota Press.

Osa, Maryjane, and Christina Corduneanu-Huci. 2003. "Running Uphill: Political Opportunity in Non-democracies." Comparative Sociology 2(4): 605-29.

Peng, Yusheng. 2010. "When Formal Laws and Informal Norms Collide: Lineage Networks versus Birth Control Policy in China." American Journal of Sociology 116(3): 770-805.

Pesqué-Cela, Vanesa, Ran Tao, Yongdong Liu, and Laixiang Sun. 2009. "Challenging, Complementing or Assuming 'the Mandate of Heaven'? Political Distrust and the Rise of Self-Governing Social Organizations in Rural China." Journal of Comparative Economics 37(1):151-68.

Petras, James, and Henry Veltmeyer. 2006. "Social Movements and the State: Political Power Dynamics in Latin America." Critical Sociology 32(1): 83-104.

Piven, Frances Fox, and Richard A. Cloward. 1992 "Normalizing Collective Protest." Pp 301325 in Frontiers in Social Movement Theory, edited by Aldon Morris, and Carol Mueller. New Haven, CT: Yale University Press.

Powell, Walter, and Rebecca Friedkin. 1987. "Organizational Change in Nonprofit Organizations." Pp. 180-92 in The Non-Profit Sector, edited by Walter Powell. New Haven, CT: Yale University Press.

Putnam, Robert D. 1993. “The Prosperous Community.” American Prospect 7: 35-42.

Riley, Dylan. 2005. "Civic Associations and Authoritarian Regimes in Interwar Europe: Italy and Spain in Comparative Perspective." American Sociological Review 70(2): 288-310.

Saich, Tony. 2000. "Negotiating the State: The Development of Social Organizations in China." The China Quarterly 161: 124-41.

Sampson, Robert J., Doug McAdam, Heather MacIndoe, and Simon Weffer-Elizondo. 2005. "Civil Society Reconsidered: The Durable Nature and Community Structure of Collective Civic Action." American Journal of Sociology 111(3): 673-714.

Schock, Kurt. 2005. Unarmed Insurrections: People Power Movements in Nondemocracies. Minneapolis: University of Minnesota Press.

Snow, David A., Louis A. Zurcher Jr., and Sheldon Ekland-Olson.1980. "Social Networks and Social Movements: A Microstructural Approach to Differential Recruitment." American Sociological Review 45(5): 787-801.

Solinger, Dorothy J. 2009. States' Gains, Labor's Losses: China, France, and Mexico Choose Global Liaisons, 1980-2000. Ithaca, NY: Cornell University Press.

Spires, Anthony J. 2011. "Contingent Symbiosis and Civil Society in an Authoritarian State: Understanding the Survival of China's Grassroots NGOs." American Journal of Sociology 117(1): 1-45.

Staggenborg, Suzanne. 1989. "Organizational and Environmental Influences on the Development of the Pro-choice Movement." Social Forces 68(1): 204-240.

Staggenborg, Suzanne. 2002. "The 'Meso' in Social Movement Research.” Pp. 124-139 in Social Movements: Identity, Culture, and the State, edited by David S. Meyer, Nancy Whittier, and Belinda Robnett. New York: Oxford University Press. 
State Council Development Research Centre. 2002. Analysis of the Features of Regional Social and Economic Development in China.

State Council. 2005. Regulations on Letters and Visits.

Streeck, Wolfgang, and Lane Kenworthy. 2005. "Theories and Practices of Neo-Corporatism." Pp. 441-60 in A Handbook of Political Sociology: States, Civil Societies and Globalization, edited by Thomas Janoski et al. New York: Cambridge University Press.

Su, Fubing, Xi Zhao, and Ran Tao. 2013. "Land Taking and Electoral Rule Setting: Evidence from Chinese Rural Democracy.” Working Paper.

Sun, Yanfei. 2014. "Popular Religion in Zhejiang Feminization, Bifurcation, and Buddhification." Modern China 40(5): 455-487.

Tao, Yu, Mingxing Liu, Yongdong Liu, Ran Tao. 2013. "Analysis of the Structure and Functions of Rural Associations in China," in Modern China Social Structure Change and Social Management.

Tarrow, Sidney. 2011. Power in Movement: Social Movements, Collective Action and Mass Politics in the Modern State. Cambridge: Cambridge University Press.

Teets, Jessica C. 2013. "Let Many Civil Societies Bloom: The Rise of Consultative Authoritarianism in China." The China Quarterly 213: 19-38.

Thurston, Anne F. 1998. Muddling toward Democracy: Political Change in Grassroots China. Washington, DC: United States Institute of Peace.

Tilly, Charles. 1978. From Mobilization to Revolution. New York: Random House.

Tilly, Charles, and Sidney G. Tarrow. 2007. Contentious Politics. New York: Oxford University Press.

Tsai, Lily L. 2007. Accountability Without Democracy: Solidary Groups and Public Goods Provision in Rural China. New York: Cambridge University Press.

Unger, Jonathan. 2008. "Chinese Associations, Civil Society, and State Corporatism: Disputed Terrain.” Pp. 1-13 in Associations and the Chinese State: Contested Spaces, edited by Jonathan Unger. New York: Sharpe.

Vala, Carsten T., and Kevin J. O’Brien. 2008. "Recruitment to Protestant House Churches.” Pp. 108-25 in Popular Protest in China, edited by Kevin J. O’Brien. Cambridge, MA: Harvard University Press.

Warren, M.E. 2001. Democracy and Association. Princeton, NJ: Princeton University Press.

Weller. 2005. "Civil Associations and Autonomy under Three Regimes: The Boundaries of State and Society in Hong Kong, Taiwan, and China" Pp. 76-94 in NGOs, Globalization and Political Change in Asia, edited by Robert P. Weller. New York: Routledge.

Wellman, Barry, and Endre Sik. 1999. "Network Capital in Capitalist, Communist, and Postcommunist Countries." Pp. 225-53 in Networks in the Global Village. Life in Contemporary Communities. Notre Dame, IN: University of Notre Dame Press.

Wong, Christine P.W. 1997. Financing Local Government in the People's Republic of China. Hong Kong, New York: Oxford University Press.

Wooldridge, Jeffrey M. 2010. Econometric Analysis of Cross Section and Panel Data. 3rd ed. Cambridge, MA: The MIT Press.

Wright, Teresa. 2008. "Student Movements in China and Taiwan." Pp. 26-53 in Popular Protest in China, edited by Kevin J. O'Brien. Cambridge, MA: Harvard University Press.

Xiao, Tangbiao. 2001. Lineage in Village Governance: Research Based on Nine Villages. Shanghai: The Press of Shanghai Book Store. 
Xing, Fuzeng. 2003. "Church-state Relations in Contemporary China and the Development of Protestant Christianity." China Study Journal 18(3): 27-40.

Yang, Fenggang. 2011. Religion in China: Survival and Revival under Communist Rule. New York: Oxford University Press.

Yu, Jianrong. 2007. Rightful Resistance of Chinese Peasants: An Investigation in Hengyang, Hunan Province. Hong Kong: The Press of Chinese Culture.

Zhang, Xin, and Richard Baum. 2004 "Civil Society and the Anatomy of a Rural NGO." The China Journal 52: 97-107.

Zhao, Dingxin. 1998. "Ecologies of Social Movements: Student Mobilization during the 1989 Prodemocracy Movement in Beijing." American Journal of Sociology 103(6): 1493-1529.

Zhou, Xueguang. 1993. "Unorganized Interests and Collective Action in China." American Sociological Review 58:54-73. 


\section{Appendix A. Scatter Diagram of Village Lineage Structure}

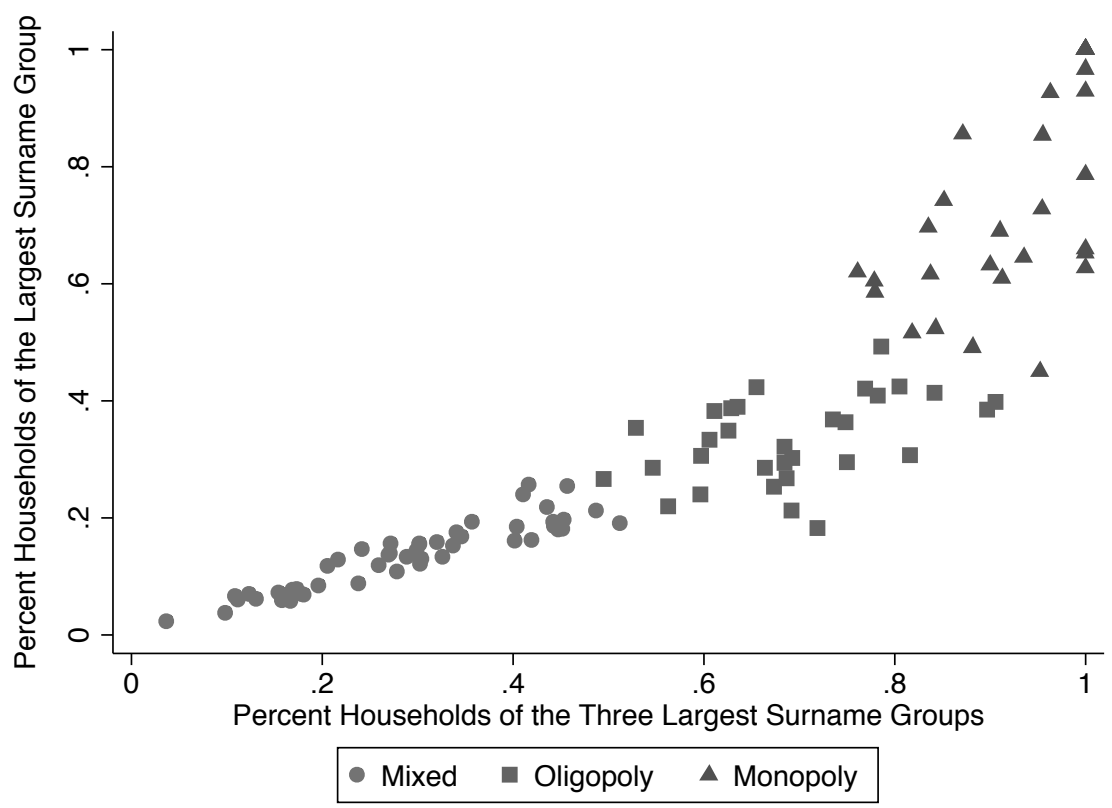

Note: Monopoly villages are dominated by a single lineage, which accounts for more than 42 percent of households. Oligopoly villages are dominated by a few large lineage groups, with no one group able to claim substantially larger numbers than the other two. In these villages, the three largest lineage groups account for more than 53 percent of households. Mixed villages comprise families from many different descent groups, with no single group accounting for more than one-quarter of households. 
Appendix B. Total Number of Collective Petitions and Protests (in parentheses) by Province in Rural China, 2004-2008

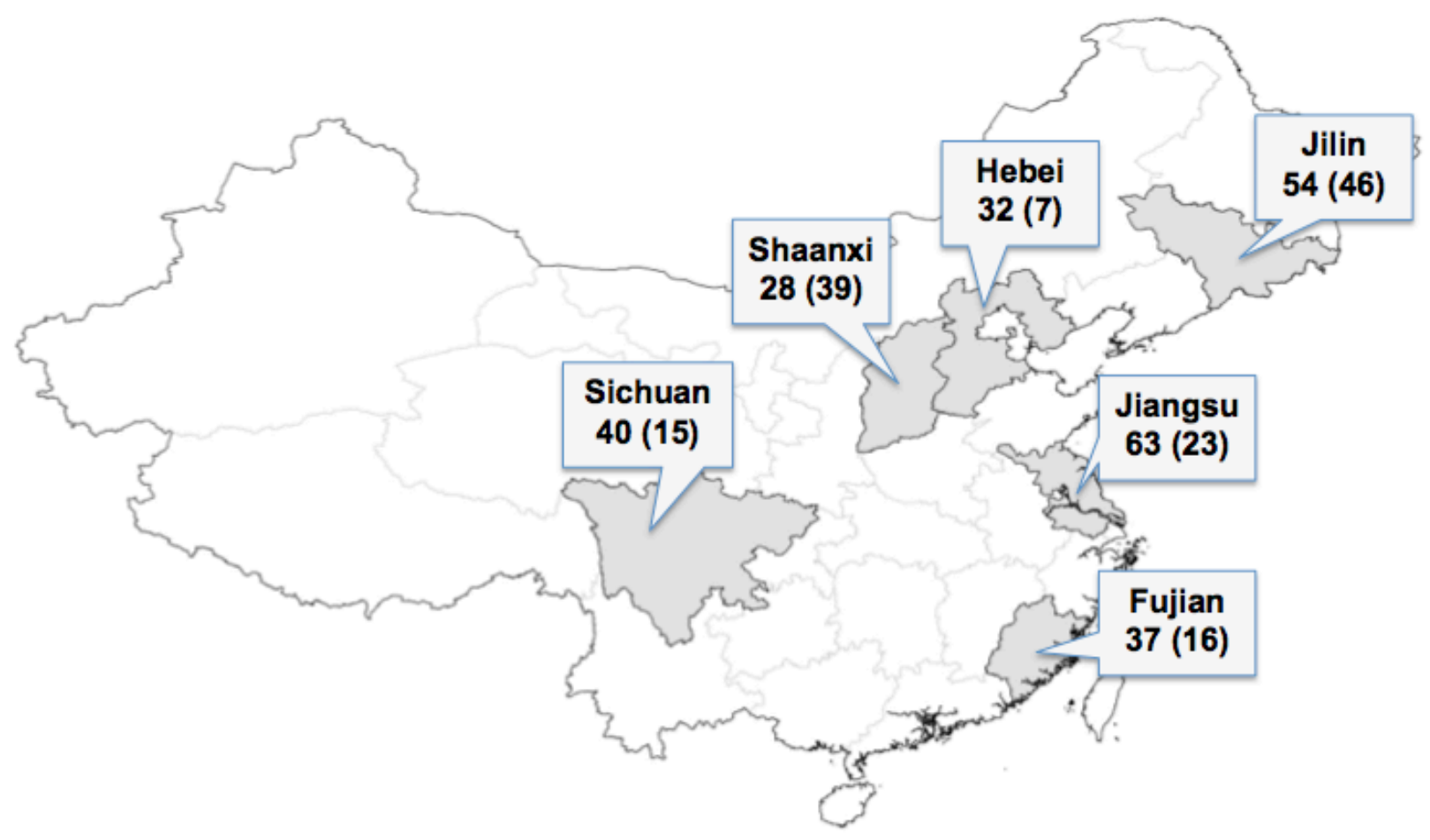




\section{Appendix C. Descriptive Statistics of Variables in Table 1}

As for other village characteristics not discussed in the main text, the percentage of villages with a temple was $44.2 \%$. The percentage with a Christian church or Islamic mosque was $26.5 \%$, with the vast majority being Christian churches. The average population size was 1,575 in 2004, increasing slightly over time. Although village per capita annual income and educational level have improved over time, they remained quite low, which is consistent with previous research on rural China. The sample villages averaged 3.6 enterprises in 2004, increasing to almost 4.5 by 2008. Other indicators of economic diversification in rural China were the declining percentage of population working exclusively in agriculture and the increasing percentage of migrants. There were very few ethnic minorities in sample villages, because minority groups concentrate in a few provinces in China. In terms of land resources, there has been a decline in per capita household farmland, reflecting the nationwide conversion of farmland to nonagricultural purposes. At the same time, the percentage of irrigated arable land has increased. Moreover, we see growing fiscal transfers from upper-level governments, which almost tripled during the fiveyear period. Finally, $62 \%$ of villages had someone working in upper-level governments in 2004; this percentage increased to almost $75 \%$ by 2008 . 


\section{Appendix D. Church and Rural Collective Resistance}

The significant coefficient of the presence of churches may indicate an important role played by churches in mobilization. Previous research (Xing 2003; Yang 2011) and our in-depth interviews, however, both point to the opposite. The Chinese government maintains tight control over religious organizations; hence, churches tend to operate under serious constraints (Xing 2003). They are largely depoliticized, deliberately disengaging themselves from local politics and almost never directly challenging the state, in exchange for room to survive (Yang 2011). Also for this reason, the presence of churches unsurprisingly does not have an impact on petitions success (Table 4).

The depoliticized nature of churches in rural China is supported by our qualitative interviews with church leaders, village cadres, and ordinary villagers. No interview revealed any direct role of churches in organizing collective resistance. Rather, the interviews are filled with counterexamples. A village party secretary (Jilin province) explained: "The church mainly preaches to villagers, and just focuses on religious activities. It doesn't get involved in village public affairs... Even when peasants' rights are violated, churches still stay out of organizing people to challenge it... The seniors association is different from the church. It often intervenes in village affairs." In another interview with a villager (Hebei Province): "The church does not have public functions (gonggong zhineng). The church and village committee coexist in peace (heping gongchu). They do not interfere in each other's business (hubu ganshe)."

We want to note a few caveats to this general finding. In rare situations, churches may confront the state, but only when their survival is at stake, such as when they face demolition due to land development, or face crackdown to counter their growing popularity and influence (Yang 2011). Moreover, the churches we examined in the study represent officially registered churches. There are growing unregistered, underground house churches that are run privately (Xing 2003). These churches may play a different role in local resistance. We have no data, however, to explicitly examine their role.

Therefore, it is more plausible that our results, rather than showing how churches work per se, point to a more fundamental process - that is, churches forge the formation of local social capital by providing an important public space in rural China. The social capital can then be activated for collective resistance in light of local grievances. In rural China, churches are more likely to emerge in villages where other types of solidarity organizations are absent or limited. This is consistent with our data showing a higher prevalence of churches in mixed-surname villages than in monopolistic and oligopolistic villages. In these places, churches provide a rare but important public and physical space (Yang 2011), which fosters local social cohesion among church members. In our interviews, villagers openly acknowledged such unity: "They are all brothers and sisters. They help each other (villager in Shannxi province)." In this respect, local networks built around church activities become a center of community involvement and facilitate information circulation and mobilization. For example, when active church members initiate collective action, they can easily pass along the information during church gatherings and draw on the close-knit network of church members (which often extend to their families) for participation. In summary, it is the informal social networks forged through church membership and activities, rather than the direct engagement of churches themselves, that foster collective 
resistance.

Xing, Fuzeng. 2003. "Church-state Relations in Contemporary China and the Development of Protestant Christianity." China Study Journal 18(3): 27-40.

Yang, Fenggang. 2011. Religion in China: Survival and Revival under Communist Rule. New York: Oxford University Press. 
Figure 1. Total Number of Collective Petitions in Sampled Villages by Year, 2004-2008

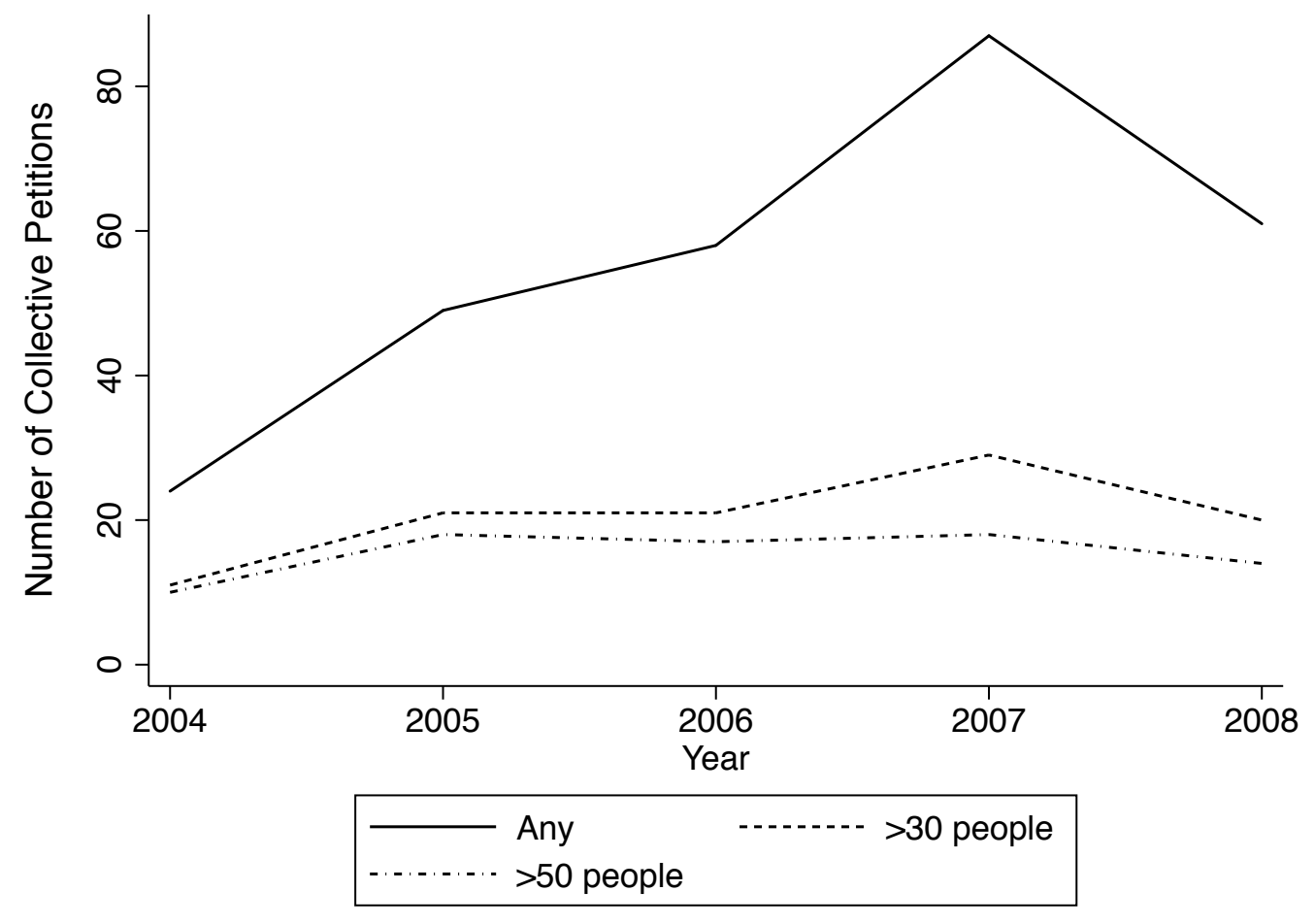


Figure 2. Total Number of Protests in Sampled Villages by Year, 2004-2008

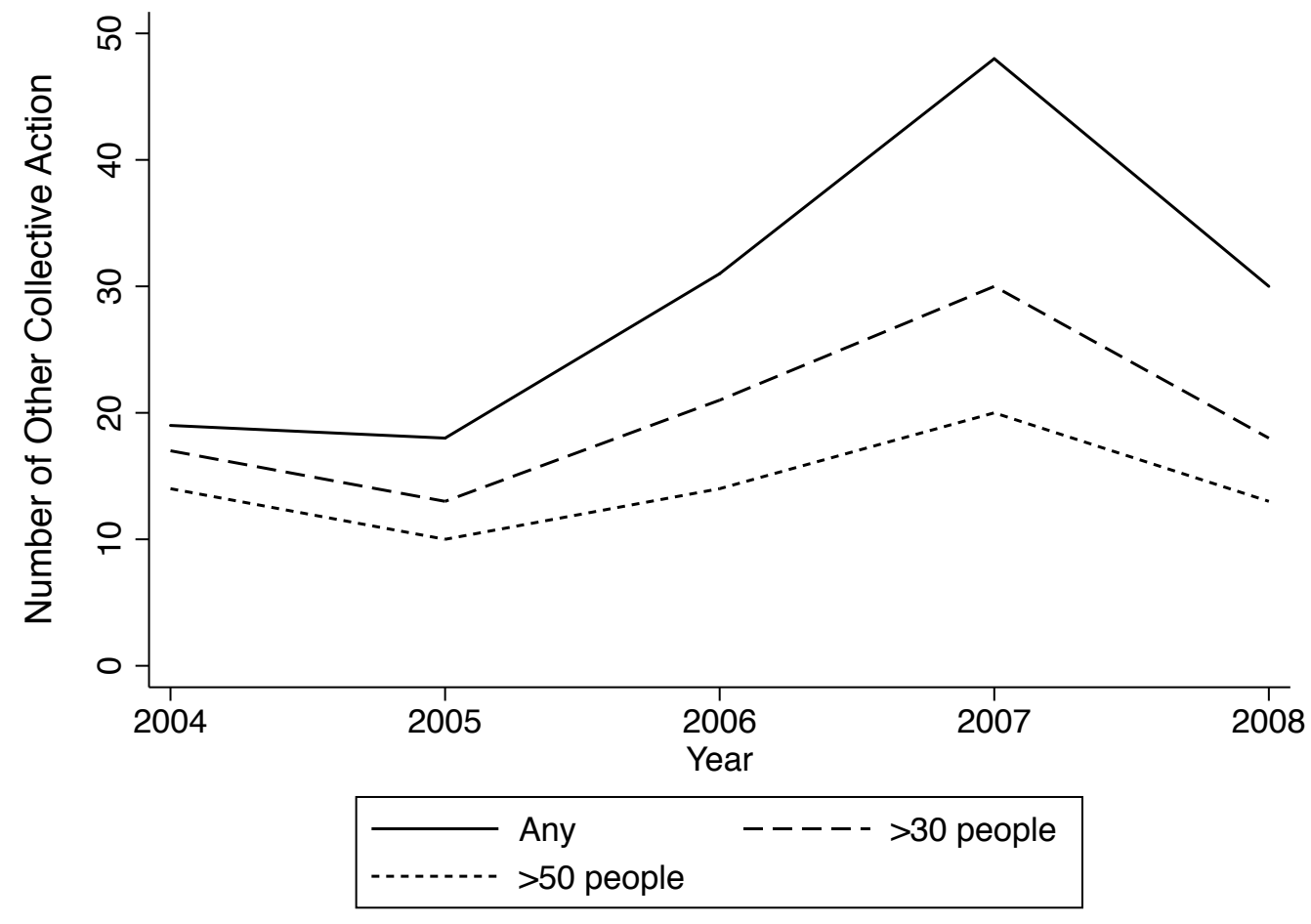


Table 1. Organizational Structure and Role in Collective Resistance

\begin{tabular}{|c|c|c|}
\hline & Lineage & Seniors association \\
\hline $\begin{array}{l}\text { Internal structure } \\
\text { (Horizontal linkages) }\end{array}$ & $\begin{array}{l}\text { *Patrilineal kinship-based ties } \\
\text { *Solidarity within lineage }\end{array}$ & $\begin{array}{l}\text { *Associational ties of elderly } \\
\text { *Social ties extending to entire village }\end{array}$ \\
\hline $\begin{array}{l}\text { External structure } \\
\text { (Vertical linkages) }\end{array}$ & $\begin{array}{l}\text { *Informal } \\
\text { *Autonomous } \\
\text { *Weak and tenuous relations with } \\
\text { local state }\end{array}$ & $\begin{array}{l}\text { *Formal } \\
{ }^{*} \text { Semi-autonomous } \\
{ }^{*} \text { Close and elaborate relations with local } \\
\text { state }\end{array}$ \\
\hline $\begin{array}{l}\text { Role in collective resistance } \\
\text { occurrence }\end{array}$ & $\begin{array}{l}\text { *Mobilizing structures } \\
{ }^{*} \text { Foster collective resistance onset }\end{array}$ & $\begin{array}{l}\text { *Mediating capacity } \\
{ }^{*} \text { Suppress collective resistance onset }\end{array}$ \\
\hline $\begin{array}{l}\text { Role in collective resistance } \\
\text { success (conditional on } \\
\text { occurrence) }\end{array}$ & $\begin{array}{l}\text { *Lacking legitimacy and vertical } \\
\text { linkages } \\
{ }^{*} \text { Limited role }\end{array}$ & $\begin{array}{l}{ }^{*} \text { Having legitimacy and vertical linkages } \\
{ }^{*} \text { Effective role }\end{array}$ \\
\hline
\end{tabular}


Table 2. Descriptive Statistics of Variables

\begin{tabular}{|c|c|c|c|c|}
\hline & \multicolumn{2}{|l|}{2004} & \multicolumn{2}{|l|}{2008} \\
\hline & Mean/Prop. & Std. Dev. & Mean/Prop. & Std. Dev. \\
\hline Collective petition $(1=$ Yes; $0=$ No $)$ & 0.16 & --- & 0.21 & --- \\
\hline $\begin{array}{l}\text { Protests and other non-institutionalized collective } \\
\text { action }(1=\text { Yes; } 0=\text { No })\end{array}$ & 0.09 & --- & 0.11 & --- \\
\hline Successful petition $(1=\text { Yes; } 0=\mathrm{No})^{\mathrm{a}}$ & --- & --- & 0.30 & --- \\
\hline Land requisition $(1=\mathrm{Yes} ; 0=\mathrm{No})$ & 0.11 & --- & 0.13 & --- \\
\hline Seniors association $(1=$ Yes; $0=$ No $)$ & 0.35 & --- & 0.35 & --- \\
\hline \multicolumn{5}{|l|}{ Lineage structure } \\
\hline Mixed & 0.44 & --- & 0.44 & --- \\
\hline Oligopoly & 0.27 & --- & 0.27 & --- \\
\hline Monopoly & 0.28 & --- & 0.28 & --- \\
\hline Temple $(1=$ Yes; $0=$ No $)$ & 0.44 & --- & 0.44 & --- \\
\hline Christian or Islamic church $(1=\mathrm{Yes} ; 0=\mathrm{No})$ & 0.27 & --- & 0.27 & --- \\
\hline Village population (unit: 1,000 people) & 1.58 & 0.98 & 1.59 & 1.02 \\
\hline Per capita annual income (yuan) & 2,808 & 1,556 & 3,911 & 2,256 \\
\hline $\begin{array}{l}\text { Proportion of population with high school or higher } \\
\text { education }\end{array}$ & 0.13 & 0.12 & 0.13 & 0.13 \\
\hline Number of enterprises & 3.62 & 8.89 & 4.46 & 10.99 \\
\hline $\begin{array}{l}\text { Proportion of population working only in agricultural } \\
\text { sector }\end{array}$ & 0.46 & 0.31 & 0.42 & 0.28 \\
\hline Proportion of population away as migrant workers & 0.28 & 0.18 & 0.34 & 0.21 \\
\hline Proportion of working-age population & 0.51 & 0.12 & 0.52 & 0.12 \\
\hline Proportion of ethnic minority & 0.06 & 0.19 & 0.05 & 0.16 \\
\hline Per capita household farmland (unit: $\mathrm{mu}$ ) & 6.86 & 10.48 & 6.45 & 9.52 \\
\hline Proportion of arable land that is irrigated & 0.56 & 0.37 & 0.64 & 0.39 \\
\hline $\begin{array}{l}\text { Per capita fiscal transfer from upper-level government } \\
\text { (yuan) }\end{array}$ & 20.31 & 39.83 & 57.15 & 86.10 \\
\hline $\begin{array}{l}\text { Villagers working in upper-level government }(1=\text { Yes; } \\
0=\text { No) }\end{array}$ & 0.62 & --- & 0.75 & --- \\
\hline$N$ & \multicolumn{2}{|c|}{113} & \multicolumn{2}{|c|}{113} \\
\hline
\end{tabular}

Note: The "mu" is a traditional unit of land area in China. One mu is about 675 square meters. The "yuan" is the Chinese currency. In 2008, one US dollar was about 6.9 Chinese yuan.

${ }^{\mathrm{a}}$ Success of petition was measured in 2008 for all petitions that occurred between 2004 and 2008. 
Table 3. Village Fixed-effect Models of Determinants of Collective Petition in Rural China, 2004-2008 (Standard Errors in Parentheses)

\begin{tabular}{|c|c|c|c|c|}
\hline & \multirow{2}{*}{$\begin{array}{l}\text { Model 1 } \\
\text { All } \\
(\text { size }>5)\end{array}$} & \multirow{2}{*}{$\begin{array}{l}\text { Model } 2 \\
\text { All } \\
(\text { size }>5)\end{array}$} & \multirow{2}{*}{$\begin{array}{l}\text { Model } 3 \\
\text { Size }>30\end{array}$} & \multirow{2}{*}{$\begin{array}{l}\text { Model } 4 \\
\text { Size }>50\end{array}$} \\
\hline & & & & \\
\hline Land requisition & $\begin{array}{l}0.20 * * \\
(0.07)\end{array}$ & $\begin{array}{l}0.11 \\
(0.11)\end{array}$ & $\begin{array}{l}0.04 \\
(0.09)\end{array}$ & $\begin{array}{l}0.08 \\
(0.08)\end{array}$ \\
\hline Seniors association $*$ Land requisition & & $\begin{array}{l}-0.46^{*} \\
(0.18)\end{array}$ & $\begin{array}{l}-0.31^{*} \\
(0.14)\end{array}$ & $\begin{array}{l}-0.37^{* *} \\
(0.13)\end{array}$ \\
\hline \multicolumn{5}{|l|}{ Lineage structure (ref. Mixed) } \\
\hline Oligopoly * Land requisition & & $\begin{array}{l}0.34 \dagger \\
(0.19)\end{array}$ & $\begin{array}{l}0.39 * * \\
(0.14)\end{array}$ & $\begin{array}{l}0.25 \dagger \\
(0.13)\end{array}$ \\
\hline Monopoly * Land requisition & & $\begin{array}{l}0.14 \\
(0.17)\end{array}$ & $\begin{array}{l}0.17 \\
(0.13)\end{array}$ & $\begin{array}{l}0.25^{*} \\
(0.12)\end{array}$ \\
\hline Temple * Land requisition & & $\begin{array}{l}0.12 \\
(0.15)\end{array}$ & $\begin{array}{l}0.09 \\
(0.12)\end{array}$ & $\begin{array}{l}0.09 \\
(0.11)\end{array}$ \\
\hline Church * Land requisition & & $\begin{array}{l}0.39^{*} \\
(0.17)\end{array}$ & $\begin{array}{l}0.30^{*} \\
(0.13)\end{array}$ & $\begin{array}{l}0.22 \dagger \\
(0.12)\end{array}$ \\
\hline Village population $(\log )$ & $\begin{array}{l}-0.05 \\
(0.17)\end{array}$ & $\begin{array}{l}-0.08 \\
(0.17)\end{array}$ & $\begin{array}{l}-0.18 \\
(0.13)\end{array}$ & $\begin{array}{l}-0.12 \\
(0.12)\end{array}$ \\
\hline Per capita annual income (log) & $\begin{array}{l}-0.02 \\
(0.20)\end{array}$ & $\begin{array}{l}-0.02 \\
(0.10)\end{array}$ & $\begin{array}{l}0.04 \\
(0.08)\end{array}$ & $\begin{array}{l}0.02 \\
(0.07)\end{array}$ \\
\hline $\begin{array}{l}\text { Proportion of population with high school or } \\
\text { higher education }\end{array}$ & $\begin{array}{l}-0.34 \\
(0.30)\end{array}$ & $\begin{array}{l}-0.40 \\
(0.30)\end{array}$ & $\begin{array}{l}-0.37 \\
(0.23)\end{array}$ & $\begin{array}{l}-0.36 \dagger \\
(0.21)\end{array}$ \\
\hline Number of enterprises & $\begin{array}{l}-0.00 \\
(0.00)\end{array}$ & $\begin{array}{l}-0.01 \\
(0.01)\end{array}$ & $\begin{array}{l}-0.00 \\
(0.00)\end{array}$ & $\begin{array}{l}-0.00 \\
(0.00)\end{array}$ \\
\hline $\begin{array}{l}\text { Proportion of population working only in } \\
\text { agricultural sector }\end{array}$ & $\begin{array}{l}-0.06 \\
(0.13)\end{array}$ & $\begin{array}{l}-0.07 \\
(0.13)\end{array}$ & $\begin{array}{l}-0.02 \\
(0.10)\end{array}$ & $\begin{array}{l}-0.11 \\
(0.09)\end{array}$ \\
\hline $\begin{array}{l}\text { Proportion of population away as migrant } \\
\text { workers }\end{array}$ & $\begin{array}{l}0.03 \\
(0.17)\end{array}$ & $\begin{array}{l}0.02 \\
(0.17)\end{array}$ & $\begin{array}{l}-0.17 \\
(0.13)\end{array}$ & $\begin{array}{l}-0.26^{*} \\
(0.12)\end{array}$ \\
\hline Proportion of working-age population & $\begin{array}{l}0.02 \\
(0.29)\end{array}$ & $\begin{array}{l}0.05 \\
(0.29)\end{array}$ & $\begin{array}{l}0.07 \\
(0.22)\end{array}$ & $\begin{array}{l}0.17 \\
(0.20)\end{array}$ \\
\hline Proportion of ethnic minority & $\begin{array}{l}0.02 \\
(0.40)\end{array}$ & $\begin{array}{l}0.05 \\
(0.40)\end{array}$ & $\begin{array}{l}0.34 \\
(0.31)\end{array}$ & $\begin{array}{l}0.33 \\
(0.28)\end{array}$ \\
\hline Per capita household farmland (log) & $\begin{array}{l}-0.09 \\
(0.09)\end{array}$ & $\begin{array}{l}-0.09 \\
(0.09)\end{array}$ & $\begin{array}{l}-0.11 \\
(0.07)\end{array}$ & $\begin{array}{l}-0.06 \\
(0.06)\end{array}$ \\
\hline Proportion of arable land that is irrigated & $\begin{array}{l}-0.12 \\
(0.14)\end{array}$ & $\begin{array}{l}-0.14 \\
(0.14)\end{array}$ & $\begin{array}{l}-0.13 \\
(0.11)\end{array}$ & $\begin{array}{l}-0.09 \\
(0.10)\end{array}$ \\
\hline $\begin{array}{l}\text { Per capita fiscal transfer from upper-level } \\
\text { government }(\log )\end{array}$ & $\begin{array}{l}-0.04 \\
(0.03)\end{array}$ & $\begin{array}{l}-0.04 \\
(0.03)\end{array}$ & $\begin{array}{l}-0.01 \\
(0.02)\end{array}$ & $\begin{array}{l}-0.01 \\
(0.02)\end{array}$ \\
\hline Villagers working in upper-level government & $\begin{array}{l}0.03 \\
(0.07)\end{array}$ & $\begin{array}{l}0.04 \\
(0.07)\end{array}$ & $\begin{array}{l}-0.03 \\
(0.05)\end{array}$ & $\begin{array}{l}0.03 \\
(0.05)\end{array}$ \\
\hline
\end{tabular}




\begin{tabular}{lllll}
2005 & $0.10^{*}$ & $0.10 \dagger$ & 0.03 & 0.04 \\
2006 & $(0.05)$ & $(0.05)$ & $(0.04)$ & $(0.04)$ \\
& $0.14^{* *}$ & $0.14^{* *}$ & 0.06 & 0.04 \\
2007 & $(0.05)$ & $(0.05)$ & $(0.04)$ & $(0.04)$ \\
& $0.16^{* *}$ & $0.17^{* *}$ & $0.12^{* *}$ & $0.08 \dagger$ \\
2008 & $(0.06)$ & $(0.06)$ & $(0.05)$ & $(0.04)$ \\
& $0.11 \dagger$ & $0.11 \dagger$ & 0.06 & 0.03 \\
Constant & $(0.06)$ & $(0.06)$ & $(0.05)$ & $(0.05)$ \\
& -0.04 & 0.01 & -0.67 & -0.30 \\
$N$ & $(0.94)$ & $(0.94)$ & $(0.72)$ & $(0.66)$ \\
\hline
\end{tabular}

$\dagger \mathrm{p}<0.1 ; * \mathrm{p}<0.05 ; * * \mathrm{p}<0.01$ (two-tailed tests) 
Table 4. Village Fixed-effect Models of Determinants of Non-institutionalized Collective Resistance in Rural China, 2004-2008 (Standard Errors in Parentheses)

\begin{tabular}{|c|c|c|c|}
\hline & Model 1 & Model 2 & Model 3 \\
\hline & All & Size $>30$ & Size $>50$ \\
\hline \multirow[t]{2}{*}{ Land requisition } & -0.10 & -0.04 & 0.01 \\
\hline & $(0.09)$ & $(0.07)$ & $(0.06)$ \\
\hline \multirow[t]{2}{*}{ Seniors association * Land requisition } & -0.25 & $-0.30 *$ & $-0.36^{* *}$ \\
\hline & $(0.15)$ & $(0.12)$ & $(0.11)$ \\
\hline \multicolumn{4}{|l|}{ Lineage structure (ref. Mixed) } \\
\hline \multirow[t]{2}{*}{ Oligopoly * Land requisition } & $0.59 * * *$ & $0.41 * *$ & $0.36^{* *}$ \\
\hline & $(0.15)$ & $(0.12)$ & $(0.11)$ \\
\hline \multirow[t]{2}{*}{ Monopoly * Land requisition } & 0.15 & $0.26^{*}$ & $0.26^{* *}$ \\
\hline & $(0.14)$ & $(0.11)$ & $(0.10)$ \\
\hline \multirow[t]{2}{*}{ Temple * Land requisition } & 0.10 & -0.01 & 0.00 \\
\hline & $(0.12)$ & $(0.10)$ & $(0.09)$ \\
\hline \multirow[t]{2}{*}{ Church $*$ Land requisition } & 0.20 & 0.19 & $0.22 *$ \\
\hline & $(0.14)$ & $(0.11)$ & $(0.10)$ \\
\hline \multirow[t]{2}{*}{ Collective petition in village } & $0.22 * * *$ & $0.19 * * *$ & $0.13 * * *$ \\
\hline & $(0.04)$ & $(0.03)$ & $(0.03)$ \\
\hline \multirow[t]{2}{*}{ Village population $(\log )$} & -0.09 & -0.10 & -0.06 \\
\hline & $(0.14)$ & $(0.11)$ & $(0.10)$ \\
\hline \multirow[t]{2}{*}{ Per capita annual income $(\log )$} & -0.04 & -0.02 & -0.06 \\
\hline & $(0.08)$ & $(0.06)$ & $(0.06)$ \\
\hline \multirow{3}{*}{$\begin{array}{l}\text { Proportion of population with high school or higher } \\
\text { education }\end{array}$} & & & \\
\hline & 0.19 & 0.08 & $0.29+$ \\
\hline & $(0.25)$ & $(0.20)$ & $(0.17)$ \\
\hline \multirow[t]{2}{*}{ Number of enterprises } & -0.00 & -0.00 & -0.00 \\
\hline & $(0.00)$ & $(0.00)$ & $(0.00)$ \\
\hline \multirow{3}{*}{$\begin{array}{l}\text { Proportion of population working only in agricultural } \\
\text { sector }\end{array}$} & & & \\
\hline & 0.18 & $0.18^{*}$ & 0.06 \\
\hline & $(0.11)$ & $(0.09)$ & $(0.08)$ \\
\hline \multirow[t]{2}{*}{ Proportion of population away as migrant workers } & $0.30^{*}$ & $0.27^{*}$ & 0.16 \\
\hline & $(0.14)$ & $(0.11)$ & $(0.10)$ \\
\hline \multirow[t]{2}{*}{ Proportion of working-age population } & 0.06 & -0.05 & -0.05 \\
\hline & $(0.24)$ & $(0.19)$ & $(0.17)$ \\
\hline \multirow[t]{2}{*}{ Proportion of ethnic minority } & 0.13 & 0.08 & -0.05 \\
\hline & $(0.33)$ & $(0.26)$ & $(0.23)$ \\
\hline \multirow[t]{2}{*}{ Per capita household farmland (log) } & -0.05 & $-0.10+$ & -0.08 \\
\hline & $(0.07)$ & $(0.06)$ & $(0.05)$ \\
\hline \multirow[t]{2}{*}{ Proportion of arable land that is irrigated } & 0.004 & 0.02 & 0.06 \\
\hline & $(0.12)$ & $(0.09)$ & $(0.08)$ \\
\hline \multirow{3}{*}{$\begin{array}{l}\text { Per capita fiscal transfer from upper-level government } \\
(\log )\end{array}$} & & & \\
\hline & -0.00 & 0.01 & -0.00 \\
\hline & $(0.02)$ & $(0.02)$ & $(0.02)$ \\
\hline \multirow[t]{2}{*}{ Villagers working in upper-level government } & -0.01 & $0.09+$ & $0.08 *$ \\
\hline & $(0.06)$ & $(0.05)$ & $(0.04)$ \\
\hline
\end{tabular}

Year (ref. 2004) 


\begin{tabular}{lccc}
2005 & -0.05 & $-0.06+$ & -0.04 \\
2006 & $(0.04)$ & $(0.03)$ & $(0.03)$ \\
& 0.05 & -0.01 & -0.01 \\
2007 & $(0.04)$ & $(0.03)$ & $(0.03)$ \\
2008 & 0.07 & -0.04 & -0.02 \\
& $(0.05)$ & $(0.04)$ & $(0.03)$ \\
Constant & 0.02 & -0.06 & -0.06 \\
$N$ & $(0.05)$ & $(0.04)$ & $(0.04)$ \\
& -0.13 & -0.57 & -0.10 \\
& $(0.77)$ & $(0.61)$ & $(0.53)$ \\
\hline
\end{tabular}

$+\mathrm{p}<0.1 ; * \mathrm{p}<0.05 ; * * \mathrm{p}<0.01 ; * * * \mathrm{p}<0.001$ (two-tailed tests)

Notes: In the protest regressions, we control for whether any collective petition occurs in the same village in the same year since protests may be adopted in combination with petitions. The coefficient is highly significant and positive. Also, the results show that out-migration ratio is positively associated with the occurrence of protests, which may suggest that migration serves as an important channel for shaping political engagement in origin communities. This is consistent with the increasing adoption of noninstitutionalized tactics among migrant workers in urban China. 
Table 5. Determinants of Successful Collective Petition in Rural China, 2004-2008 (Standard Errors in Parentheses)

\begin{tabular}{|c|c|c|}
\hline & Model 1 & Model 2 \\
\hline & Petition-level & Village-level \\
\hline \multirow[t]{2}{*}{ Seniors association } & $0.80 *$ & $0.41 *$ \\
\hline & $(0.32)$ & $(0.20)$ \\
\hline \multicolumn{3}{|l|}{ Lineage structure (ref. Mixed) } \\
\hline \multirow[t]{2}{*}{ Oligopoly } & -0.03 & -0.11 \\
\hline & $(0.37)$ & $(0.14)$ \\
\hline \multirow[t]{2}{*}{ Monopoly } & -0.49 & -0.10 \\
\hline & $(0.35)$ & $(0.22)$ \\
\hline \multirow[t]{2}{*}{ Temple * Land requisition } & -0.22 & -0.14 \\
\hline & $(0.32)$ & $(0.20)$ \\
\hline \multirow[t]{2}{*}{ Church * Land requisition } & 0.09 & 0.05 \\
\hline & $(0.30)$ & $(0.18)$ \\
\hline \multirow[t]{2}{*}{ Village population (log) } & 0.56 & 0.32 \\
\hline & $(0.37)$ & $(0.19)$ \\
\hline \multirow[t]{2}{*}{ Per capita annual income (log) } & -0.49 & -0.30 \\
\hline & $(0.34)$ & $(0.21)$ \\
\hline \multirow[t]{2}{*}{ Proportion of population with high school or higher education } & $2.08^{*}$ & $1.23+$ \\
\hline & $(0.97)$ & $(0.74)$ \\
\hline \multirow[t]{2}{*}{ Number of enterprises } & -0.00 & -0.00 \\
\hline & $(0.01)$ & $(0.01)$ \\
\hline \multirow[t]{2}{*}{ Proportion of population working only in agricultural sector } & -0.14 & -0.07 \\
\hline & $(0.50)$ & $(0.31)$ \\
\hline \multirow[t]{2}{*}{ Proportion of population away as migrant workers } & -0.18 & -0.09 \\
\hline & $(0.82)$ & $(0.47)$ \\
\hline \multirow[t]{2}{*}{ Proportion of working-age population } & 0.00 & 0.00 \\
\hline & $(0.00)$ & $(0.00)$ \\
\hline \multirow[t]{2}{*}{ Proportion of ethnic minority } & 0.42 & 0.32 \\
\hline & $(1.24)$ & $(0.71)$ \\
\hline \multirow[t]{2}{*}{ Per capita household farmland (log) } & 0.23 & -- \\
\hline & $(0.14)$ & -- \\
\hline \multirow[t]{2}{*}{ Proportion of arable land that is irrigated } & 0.47 & -- \\
\hline & $(0.47)$ & -- \\
\hline \multirow[t]{2}{*}{ Per capita fiscal transfer from upper-level government $(\log )$} & $-0.14+$ & -0.08 \\
\hline & $(0.08)$ & $(0.07)$ \\
\hline \multirow[t]{2}{*}{ Villagers working in upper-level government } & 0.03 & 0.01 \\
\hline & $(0.30)$ & $(0.17)$ \\
\hline \multirow[t]{2}{*}{ Petition size $(\log )$} & 0.03 & 0.02 \\
\hline & $(0.08)$ & $(0.05)$ \\
\hline \multirow[t]{2}{*}{ Constant } & $4.38^{*}$ & $2.57+$ \\
\hline & $(2.03)$ & $(1.55)$ \\
\hline$N$ & 254 & 565 \\
\hline
\end{tabular}

$+\mathrm{p}<0.1 ; * \mathrm{p}<0.05$ (two-tailed tests)

Notes: Model 1 is based on logistic regression at the petition level. Model 2 is based on Heckman twostage selection probit regression at the village level (the regression omits variables of land conditions as 
they are used to identify the model). Coefficients rather than odds ratios are shown. Coefficients for year and province are omitted. In the success models, the coefficient of the size of collective petitions is insignificant. This is presumably because petitions are handled through institutional channels and are less disruptive to social order than protests. Thus, larger-scale petitions do not necessarily generate greater pressure on local authorities. Also, the coefficient of the presence of villagers working in upper-level government is small and insignificant. This suggests that interpersonal ties with state authorities play a quite limited role compared to the formalized vertical linkages encompassed by seniors associations. 